\title{
Indirect and direct recharges in a tropical forested watershed: Mule Hole, India
}

\author{
Jean-Christophe Maréchal ${ }^{1,2}$, R. R. V. Murari ${ }^{1,3}$, Jean Riotte ${ }^{1,2}$, Jean-Michel Vouillamoz ${ }^{1,4}$, \\ M. S. Mohan Kumar ${ }^{1,3}$, Laurent Ruiz ${ }^{5}$, M. Sekhar ${ }^{1,3}$, Jean-Jacques Braun ${ }^{1,2}$ \\ ${ }^{1}$ Indo-French Cell for Water Sciences, IISc-IRD Joint laboratory, Indian Institute of Science, \\ 560012 Bangalore, India \\ ${ }^{2}$ LMTG, Université de Toulouse, CNRS, IRD, OMP, 14 avenue Edouard Belin, 31400 \\ Toulouse, France \\ ${ }^{3}$ Department of Civil Engineering, Indian Institute of Science, 560012, Bangalore, India \\ ${ }^{4}$ LTHE, Université de Grenoble, CNRS, IRD, BP53, 38041 Grenoble, Cedex 9, France \\ ${ }^{5}$ INRA Agrocampus Rennes, UMR, Sol-Agronomie-Spatialisation, 65 rue de St Brieuc, CS \\ 82415, 35042 Rennes, France
}

\begin{abstract}
It is commonly accepted that forest plays role to modify the water cycle at the watershed scale. However, the impact of forest on aquifer recharge is still discussed: some studies indicate that infiltration is facilitated under forest while other studies suggest a decrease of recharge. This paper presents an estimate of recharge rates to groundwater in a humid forested watershed of India. Recharge estimates are based on the joint use of several methods: chloride mass balance, water table fluctuation, geophysics, groundwater chemistry and flow analysis. Two components of the recharge (direct and indirect) are estimated over 3 years of monitoring (2003-2006). The direct and localized recharges resulting from rainfall over the entire watershed surface area is estimated to $45 \mathrm{~mm} / \mathrm{yr}$ while the indirect recharge occurring from the stream during flood events is estimated to $30 \mathrm{~mm} / \mathrm{yr}$ for a two $\mathrm{km}$-long stream. Calculated recharge rates, rainfall and runoff measurements are then combined in a water budget to estimate yearly evapotranspiration which ranges from 80 to $90 \%$ of the rainfall, i.e. $1050 \mathrm{~mm} / \mathrm{y}$ as an average. This unexpected high value for a deciduous forest is nevertheless in agreement with the forest worldwide relationship between rainfall and evapotranspiration. The large evapotranspiration form the forest cover contributes to decrease the recharge rate which leads to a lowering of the water table. This is the reason why the stream is highly ephemeral.
\end{abstract}

\section{Introduction}

The correct estimate of natural recharge is a key element for the good management of groundwater resources. This important component of the hydrological cycle is dependant on various physical characteristics of the watershed: soil properties, topography, land-use and vegetation cover among the most significant. The impact of forests on the water yield (runoff + recharge) of a watershed is a question of interest and is still debated. Vast majority of studies indicate decreased runoff from areas under forests as compared with areas under shorter land covers (Jewitt, 2005). References on effects of forestation on natural recharge are less abundant specially in fractured crystalline aquifers. Preliminary studies in Australia have shown that clearing of natural woodland or forest has resulted in the increase of recharge and rise of the water tables (Williamson, 1990). Sharma et al. (1987) arrived to the same conclusion after forest clearing in lateritic environment. On the contrary, some studies show there is usually less soil compaction in forests and, depending on soil type, soil structure may improve causing more rainfall to infiltrate (Bruijnzeel, 2004; Ilstedt et al., 2007). 
The total recharge to groundwater is constituted by three main components. Direct recharge refers to diffuse recharge, such as from precipitation, whereas indirect recharge results from the percolation of a part of runoff water through the stream beds, and localized recharge refers to concentrated recharge by preferential flow through cracks, joints and fissures (Lerner et al., 1990). The relative proportions of these components fluctuate according to climatic conditions, geomorphology and geology. In arid climatic regions, the most important mechanism of groundwater recharge is considered to be infiltration from floods through the alluvial beds of ephemeral streams in wadi channels (Sorman et al., 1997). Except in karst hydrology, up to now, there are only few examples in the literature of the assessment of indirect recharge from a stream (Sorman et al., 1997). The assessment and regional consequences of indirect recharge constitute two challenges for the future research on recharge (de Vries and Simmers, 2002). This is specially challenging when this component highly fluctuates with time and space in the case of an ephemeral stream on an heterogeneous aquifer.

The aims of this study are (i) to identify significant recharge processes at the watershed scale in a forested area and (ii) to assess the direct, localized and indirect transient recharge rates. In order to reach these objectives, a combination of several approaches focusing on the saturated zone - chloride mass balance, water table fluctuation, geophysical investigations, pumping tests and groundwater flow modeling - is used. This study has been conducted on an experimental watershed in humid conditions located on the Indian crystalline basement. The watershed is the object of an integrated study including soil dynamics and erosion process (Barbiero et al., 2007), geophysical investigations (Descloitres et al., 2008) and hydrological and biogeochemical cycles (Braun et al., 2008).

\section{Fields setting and methodology}

The Mule Hole experimental watershed is situated in the Western Ghâts, in south India (Figure 1), at $11^{\circ} 44^{\prime} \mathrm{N}$ and $76^{\circ} 27^{\prime} \mathrm{E}$ (Karnataka state, Chamrajnagar district). The watershed area $\left(4.1 \mathrm{~km}^{2}\right)$ is mostly undulating with gentle slopes and the elevation of the watershed ranges from 820 to $910 \mathrm{~m}$ above mean sea level. The watershed is covered by a dry deciduous forest.

The study site is located in the climatic semi-humid transition area and the mean annual rainfall ( $n=20$ years) is $P=1120 \mathrm{~mm}$. The mean yearly temperature is $27{ }^{\circ} \mathrm{C}$. On the basis of the aridity index $(A I)$ defined as the ratio of mean annual precipitation $(P)$ to potential evapotranspiration for grass reference $\left(E T_{0}\right): A I=P / E T_{0}=1.2$, the climate regime can be classified as humid (UNESCO, 1979). Nevertheless, the climate is characterized by recurrent but non-periodic droughts, depending on monsoon rainfalls.

The substratum belongs to the Precambrian Dharwar supergroup (Moyen et al., 2001) and consists of gneiss with amphibolites and quartz dykes. The mean strike value is $\mathrm{N} 80^{\circ}$, with a dip angle ranging from $75^{\circ}$ to the vertical. Because of the dominant erosion process in such a head catchment, no fine deposit is present in the stream bed.

Geophysical measurements have been carried out to estimate the main geological units at the watershed scale (Descloitres et al., 2008) (Figure 1). 2D Electrical resististivity tomography (ERT) interpretation showed that (i) fresh bedrock is strongly affected by sub-vertical fractures, (ii) bedrock is overlaid by a thin weathered-fissured zone (see (Dewandel et al., 2006) for its definition) of few meters, and then by weathered material ranging from clayey to sandy rocks, and (iii) the depth to the bedrocks is highly heterogeneous, i.e. from few meters to few tens of meters at the watershed outlet area. Magnetic resonance soundings (MRS) have been also implemented on the watershed (Legchenko et al., 2006). MRS interpretation indicated that the main groundwater reservoir is located in the weathered-fissured zone of the 
bedrock. Further, timelaps geophysical measurements of both ERT and MRS conducted at the outlet of the watershed indicated a seasonal infiltration of water under the stream (Descloitres et al., 2008).

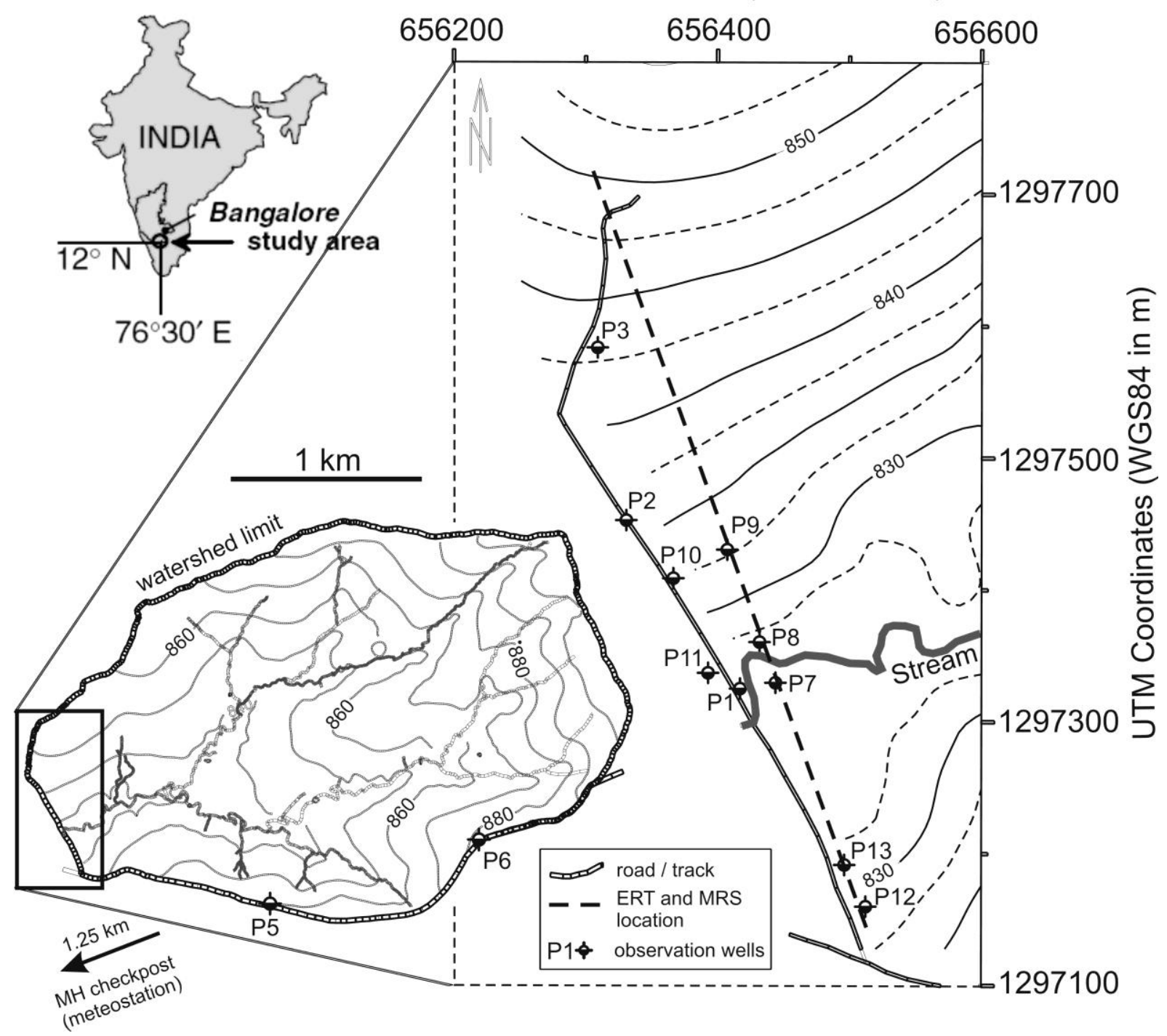

Figure 1: Location map of the experimental site at the outlet of the Mule Hole watershed (modified from Descloitres et al., 2008). Collapsed observation well P4 is not represented.

A set of 13 observation wells (named P1 - P13) have been drilled in the area. In this National Park hosting protected wildlife, authorization has been obtained for drilling along the existing tracks only. Three wells (P3, P5 and P6 on Figure 1) have been drilled at the boundaries of the watershed in order to obtain the background characteristics of the aquifer far away from the main flowing stream network. The last ten wells (including collapsed well P4) have been drilled along a straight line crossing the stream axis at its outlet (Figure 1) in order to monitor the effects of water seepage from the stream. The water levels have been monitored in all the wells from their drilling time up to now either manually at a monthly time step or automatically at a hourly time-step (Table 1). 


\begin{tabular}{|c|c|c|c|c|}
\hline Water & Location & Period of monitoring & $\begin{array}{c}\text { Time-step (water } \\
\text { levels) }\end{array}$ & $\begin{array}{c}\text { Sampling time- } \\
\text { step }\end{array}$ \\
\hline Rainfall & $\begin{array}{c}\text { Mule Hole } \\
\text { checkpost }\end{array}$ & July 2003 - December 2006 & Hourly & Daily \\
\hline Runoff & Outlet & July 2003 - December 2006 & 10 minutes & $20-90$ minutes \\
\hline \multirow{5}{*}{ Groundwater } & P1, P2, P3 & May 2003 - December 2006 & Hourly & Monthly \\
\cline { 2 - 5 } & P5, P6 & July 2003 - December 2006 & Monthly & Monthly \\
\cline { 2 - 5 } & $\begin{array}{c}\text { P7, P8, P9, } \\
\text { P10, P12 }\end{array}$ & May 2004 - December 2006 & $\begin{array}{c}\text { Monthly and Hourly } \\
\text { (from March 2005) }\end{array}$ & Monthly \\
\hline & P11 & May 2004 - December 2006 & $\begin{array}{c}\text { Monthly and Hourly } \\
\text { (from August 2005) }\end{array}$ & Monthly \\
\hline
\end{tabular}

Table 1: characteristics of monitored data

Runoff at the outlet has been measured by a stream gaging station composed by a water level indicator coupled with a Doppler-flowmeter located in a specially designed section of the stream (the error on discharge rate is assumed to be less than $20 \%$ ). Rainfall has been measured at a meteorological station located at Mule Hole checkpost (Figure 1) with an estimated error of $6 \%$. Rainfall and runoff measured at the outlet of the Mule Hole watershed were respectively, $1 \mathrm{~mm}$ and $431 \mathrm{~mm}$ in 2003 (from $1^{\text {st }}$ July 2003), $1216 \mathrm{~mm}$ and $66 \mathrm{~mm}$ in 2004, $1434 \mathrm{~mm}$ and $196 \mathrm{~mm}$ in 2005 and $1170 \mathrm{~mm}$ and $52 \mathrm{~mm}$ in 2006. During three and half hydrological years of monitoring from $1^{\text {st }}$ July 2003 to $31^{\text {st }}$ December 2006, the stream has flown only an equivalent period of 147 days, i.e. $11 \%$ of the monitoring period or about 42 days a year. The stream is therefore highly ephemeral with very fast recession periods and flows only in response to specific heavy rainfall events.

Apart from rainfall, the meteorological station provides hourly time series of humidity, temperature and wind speed. As the watershed is mainly forested, the reference evapotranspiration $\left(E T_{r}\right)$ has been computed at a hourly time step using the Penman-Montheit equation using alfalfa (tall: 0.5 meter) coefficients $C_{n}=66, C_{d}=0.25$ for daytime and $C_{d}=$ 1.7 for nightime (Allen et al., 2006).

Bulk rain samplers continuously open to the atmosphere have been used to sample bulk deposition close to the meteorological station (checkpost, Figure 1). Chlorine concentrations were measured using an Ion Chromatograph Dionex 600, with a detection limit lower than 1 $\mu \mathrm{mol} / \mathrm{L}$ and an analytical error less than $5 \%$.

The recharge has been determined using the Chloride Mass Balance (CMB) method in the observation wells. This method is based on the assumption of conservation of mass between the input of atmospheric chloride and the chloride flux in the subsurface (Dettinger, 1989). 


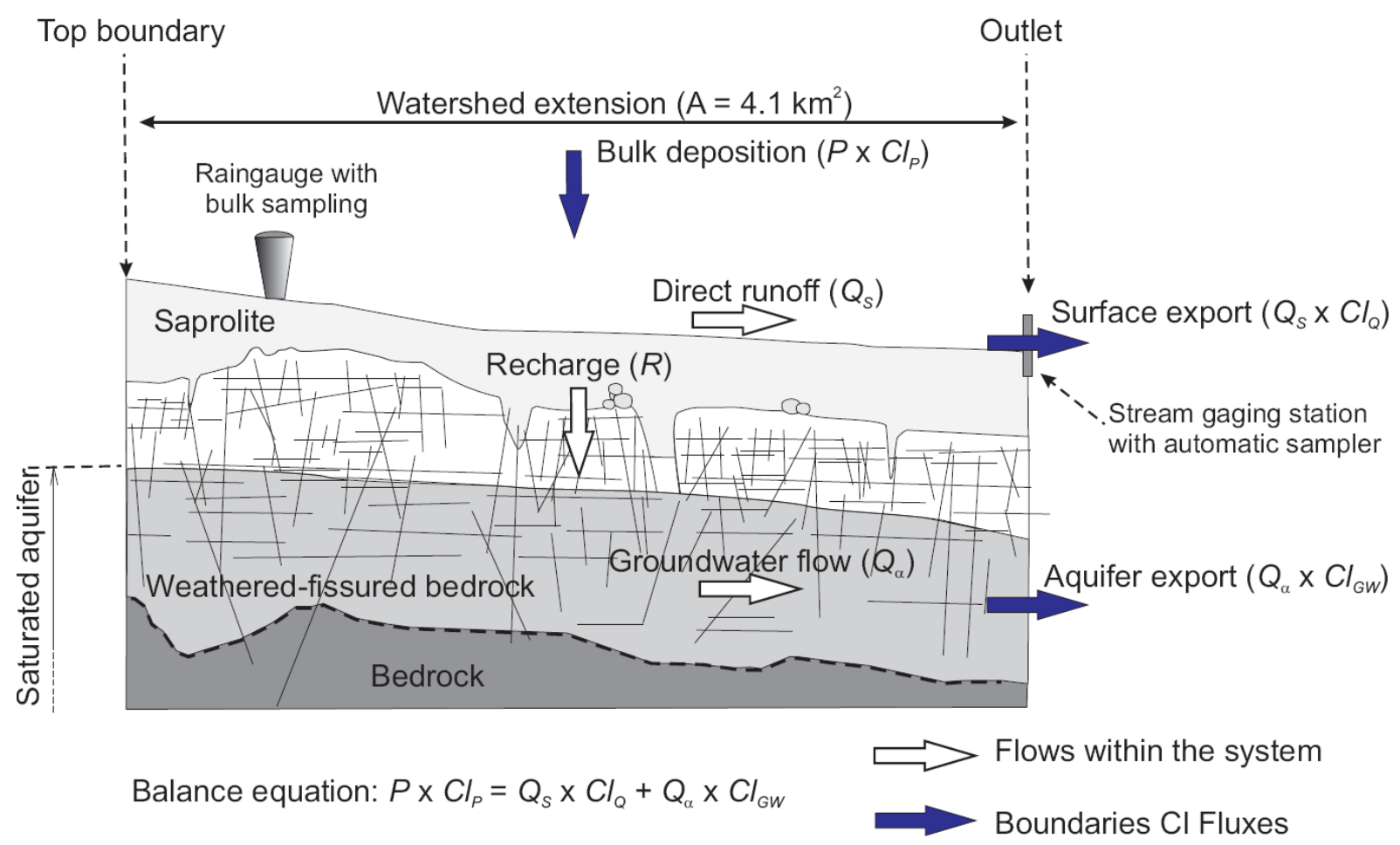

Figure 2: chloride mass balance in a small head watershed with water table disconnected from the ground and runoff measurements at the outlet.

Considering (i) an unsaturated zone where evapotranspiration and mixing of rainfall and pore water takes place, (ii) measurements of runoff at the outlet, (iii) a recharged aquifer which flows below the outlet of a small head watershed and does not contribute to the direct runoff at the outlet (Figure 2), the equation of chloride mass balance is:

$$
P C l_{P}=Q_{S} C l_{Q}+Q_{\alpha} C l_{G W}
$$

with $C l_{P}$ : weight-average chloride concentration in bulk precipitation ( $\left.\mu \mathrm{mol} / \mathrm{l}\right), C l_{Q}$ : weightaverage chloride concentration in runoff $(\mu \mathrm{mol} / \mathrm{l}), C l_{G W}$ : average chloride concentration in groundwater $(\mu \mathrm{mol} / \mathrm{l}), P$ : average precipitation rate $(1 / \mathrm{yr}), Q_{S}:$ average runoff $(1 / \mathrm{yr})$ and $Q_{\alpha}$ : average groundwater outflow (1/yr), all these values being averages on the sampling period. Assuming that the annual groundwater outflow is equal to the annual recharge rate $\left(Q_{\alpha}=R\right)$ which corresponds to the absence of long-term systematic increase or depletion of the water table, the recharge rate $(R)$ through the unsaturated zone can be calculated by:

$$
R=\frac{P C l_{P}-Q_{S} C l_{Q}}{C l_{G W}}
$$

In considering the runoff component, Equation (1) becomes an extended version of the equation commonly used in the literature for recharge estimation (Bazuhair and Wood, 1996; Wood and Sanford, 1995). This equation can be used in transient conditions provided a regular and long (several years) monitoring of chloride is conducted on rainfall, surface and groundwater. The weight-average chloride in precipitation and runoff are calculated using same equations than (Wood and Sanford, 1995). A simple average is calculated for chloride in groundwater using waters regularly sampled in observation wells.

Some recent studies have shown that chloride can be temporarily retained in the soils due to interaction with organic matter (Öberg and Sandén, 2005). It appears that the delays of the involved processes are at most a few months. This is irrelevant for long-term aquifer recharge estimation using several years data (Alcalá and Custodio, 2008; Scanlon et al., 2006) and equation (2) can be used for recharge estimation. 
In the Mule Hole watershed, the substratum is free of evaporites and very poor in chlorine bearing minerals. Moreover, the watershed has been preserved from human activity since the $17^{\text {th }}$ Century at least, because it belonged to the Maharaja of Mysore and has been later incorporated into the Bandipur National Park. Then, it may be reasonably considered that chloride comes from atmospheric deposition only and that the CMB technique method can be applied with accuracy.

Assuming an analytical error of $5 \%$ on chloride content measurements in waters, an instrumental error of $6 \%$ on rainfall amount and $20 \%$ on runoff gauging, a total error of 20 $\%$ is obtained on recharge estimates.

\section{Results}

\subsection{Groundwater flows and water levels time series}

During the dry season, decreasing water levels from P6 to P5 and to the western wells-line suggest a regional groundwater system flowing roughly from the east to the west. Far away from the stream (wells P3, P5 and P6), the water table remains deep below the stream level even during the monsoon. The water table is then always disconnected from the stream (see a schematic cross section at Figure 2). This explains the absence of springs in the watershed and the absence of baseflow measured at the outlet. Below the stream, water seepage recharges the aquifer as shown by time-lapse geophysical investigations (Descloitres et al., 2008). At the experimental site, the stream has incised the soils profiles (Barbiero et al., 2007), therefore the case study corresponds to a disconnected losing stream without clogged streambed and with a shallow water table (Peterson and Wilson, 1988).

At the experimental site crossing the stream axis, water table fluctuates according to the monsoon regime. The water levels are located at an average depth of 8 meters below the stream bed during the dry season. During the monsoon, the water levels rise close to the stream (at monitoring wells P1 and P7) up to a level of about one meter below the stream bed. The water table fluctuations $(\Delta h)$ between pre- and post-monsoon seasons are highly variable in space. The influence of the distance to the stream network on the water table level is analyzed in Figure 3 where three groups of wells can be identified. Group 1 (wells P3, P5 and P6) is characterized by small water table fluctuations $(\Delta h<2.5 \mathrm{~m})$ observed at wells far away (> $200 \mathrm{~m}$ ) from the nearest stream. Wells of group 2 (P8, P9, P10, P12, P13), located in the vicinity of the watershed flowing streams (distance comprised between 40 and $200 \mathrm{~m}$ ), show medium water level fluctuations $(3<\Delta h<5 \mathrm{~m})$. Group 3 (P1, P7, P11) is constituted by wells located in the close vicinity of surface stream $(<40 \mathrm{~m})$ and characterized by high $(\Delta h>7 \mathrm{~m})$ water level fluctuations. This relationship between water level fluctuations and distance to the surface stream confirms the existence of a heterogeneity in the recharge process mainly caused by the losing stream. 


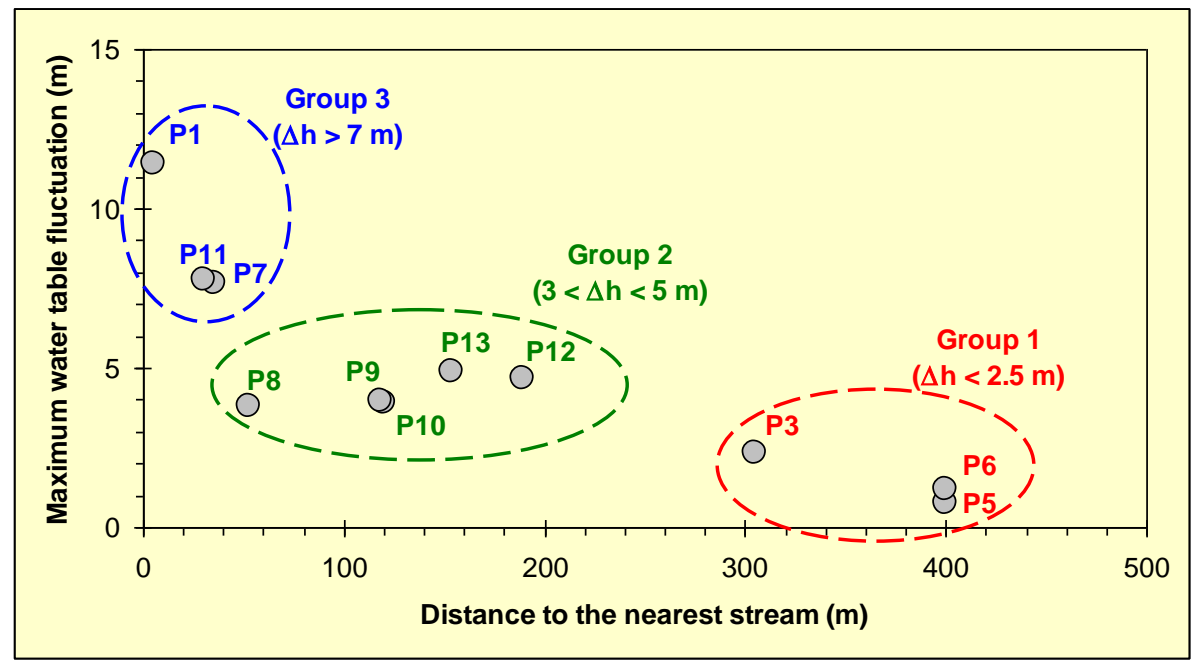

Figure 3: maximum water level fluctuation observed during the period 2003-2006 as a function of the distance from the nearest surface streams (P2 not mentioned as water table fluctuations are perturbed by rainfall infiltration into the well tube)

The analysis of water level fluctuations in wells from group 3 provides information on the dynamics of indirect recharge from the stream. For instance, the response of this group (wells P1 and P7) to the first rain events of April - June 2005 is very sharp (Figure 4). During the first event identified (57 $\mathrm{mm}$ rainfall on $10^{\text {th }}$ April), the water levels rose by $3.7 \mathrm{~m}$ in 46 hours at P1 and by $2.2 \mathrm{~m}$ in 56 hours at P7. At the same time, the water level rose gently by $0.61 \mathrm{~m}$ in 17 days at P13 (group 2). Wells P3 (group 1) and P10 (group 2) do not show any response to these events. During the second event (17 mm rainfall on $27^{\text {th }}$ April), the water levels rose by $3.37 \mathrm{~m}$ in 63 hours at $\mathrm{P} 1$ and by $2.9 \mathrm{~m}$ in 68 hours at P7 while the rise is only $0.56 \mathrm{~m}$ in 11 days at P13. After, despite several rainy events (i.e., $38 \mathrm{~mm}$ on $25^{\text {th }}$ May and $29 \mathrm{~mm}$ on $20^{\text {th }}$ June) the water levels in all the wells decrease in the absence of any runoff in the stream. Both large water level fluctuations are correlated with runoff occurrence in the stream. During the whole observation period, the water levels are higher below the stream-axis than elsewhere which results in a groundwater mound. The resulting hydraulic gradient potentially induces groundwater flows from the stream axis towards North and South.

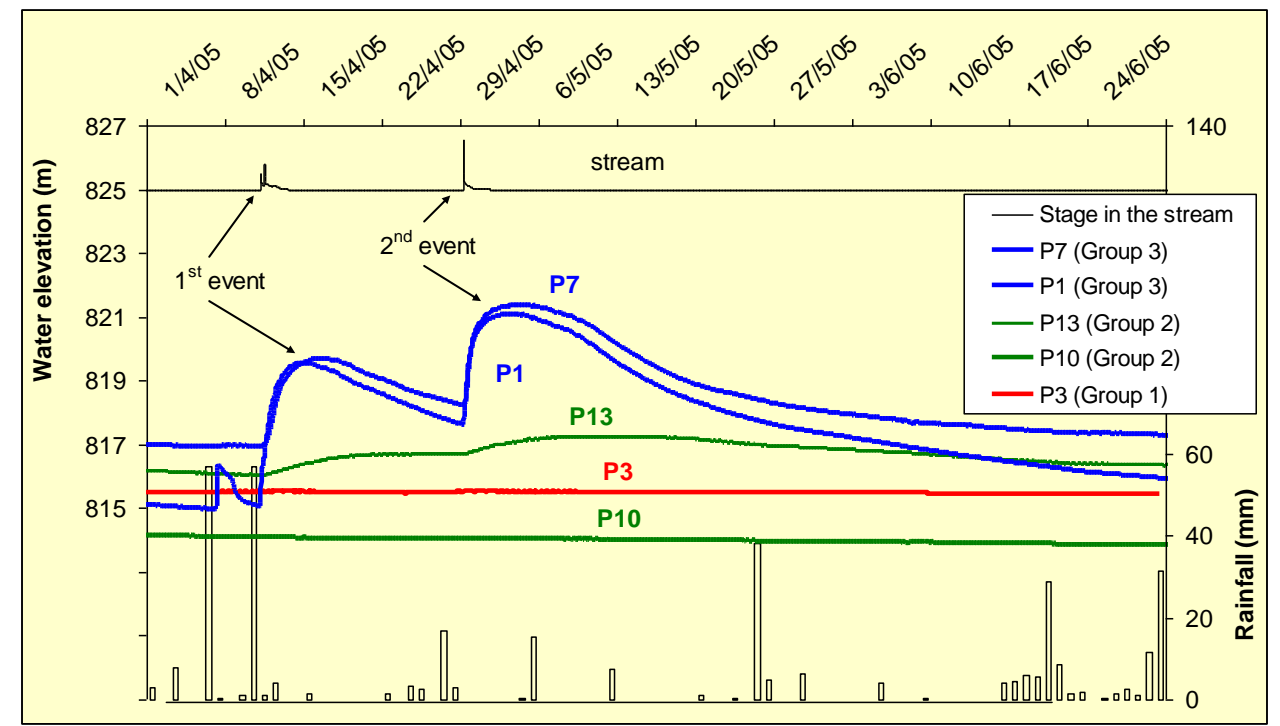

Figure 4: hourly water levels in the stream and observation wells; April - June 2005 
The water table fluctuations in wells $\mathrm{P} 1$ and $\mathrm{P} 7$ close to the stream are linked to direct recharge from rainfall and indirect recharge from the stream. The relationships between rainfall and stream head as input function and water levels below the stream as output have been evaluated using a cross-correlation analysis in order to estimate the relative importance of both processes. Despite it is low in both cases, the correlation coefficient is clearly higher for the stream / aquifer relationship than for rainfall / aquifer relationship (Figure 5). The influence of the seepage from the stream is preponderant for the water level signal at wells P1 and P7 from group 3. In other words, the water table fluctuations at wells P1 and P7 are more dependants on the stream head than on rainfall. The low average correlation coefficient is induced by the difference in the duration of input and output events: short rainfall and storm events are not well correlated to long-duration water table fluctuations.

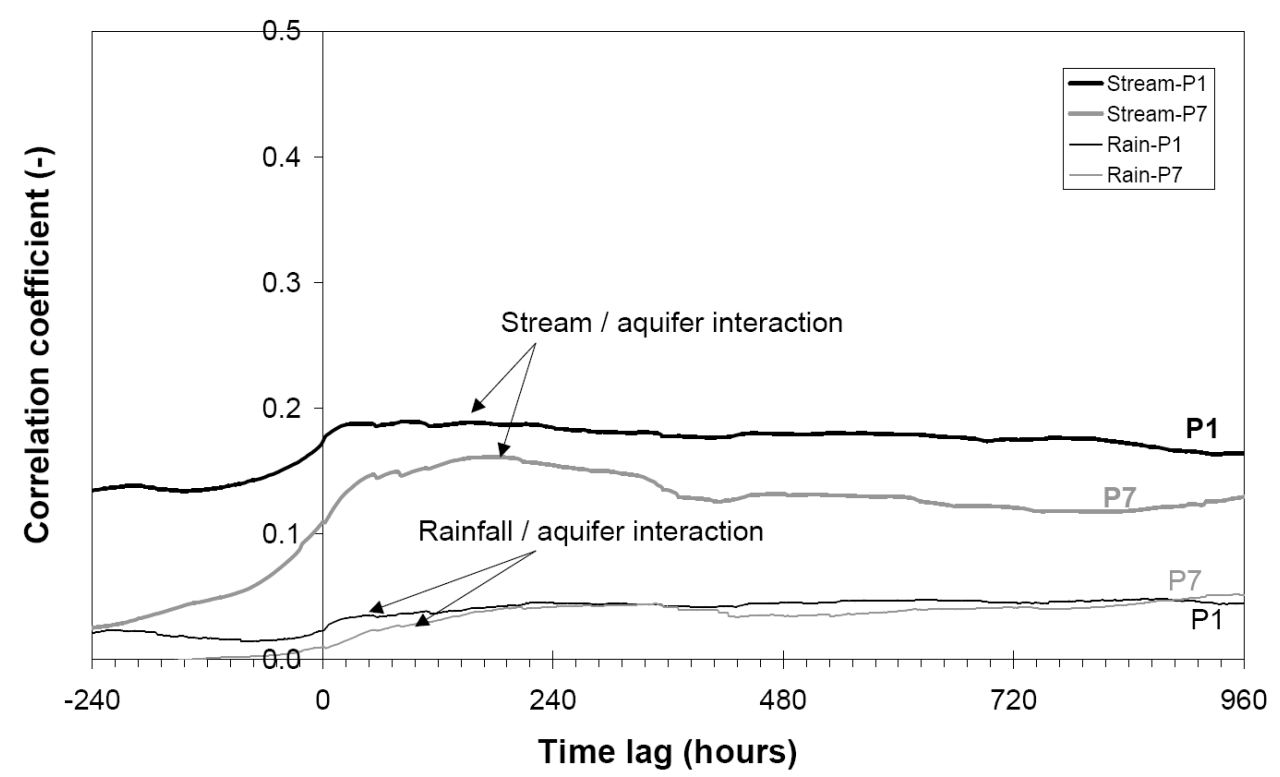

Figure 5: cross-correlation of rainfall data and water levels in the stream with water levels in monitoring wells P1 and P7 (group 3), monitored from 2003 to 2006 at hourly time step.

\subsection{Chemical content of waters}

The chloride concentrations in rainfall during the survey from 2003 to 2006 range from 1 to $129 \mu \mathrm{mol} / \mathrm{l}(n=202)$. The weight-average concentration is $24.6 \pm 1.2 \mu \mathrm{mol} / \mathrm{l}$, which corresponds to an input flux of chloride of $275 \pm 30 \mathrm{~mol} / \mathrm{ha} / \mathrm{yr}$. The $\mathrm{Na} / \mathrm{Cl}$ molar ratio is 0.71 , within the range $0.70-0.85$ classically found for seawater derived rainfall (Möller, 1990).

The chloride concentrations in surface water at the outlet during the survey from 2003 to 2006 range from 16 to $164 \mu \mathrm{mol} / 1(n=198)$. The weighted chloride concentration in surface water is $38.1 \pm 1.9 \mu \mathrm{mol} / \mathrm{l}$. The mean discharge rate on $2003-2006$ period at the outlet is $Q_{S}=3.24$ $\mathrm{x} 10^{5} \mathrm{~m}^{3} / \mathrm{yr}(79 \pm 16 \mathrm{~mm} / \mathrm{yr}$ on average $)$ and the resulting total output flux of chloride is $30 \pm$ $7.5 \mathrm{~mol} / \mathrm{ha} / \mathrm{yr}$.

The partition of groundwater into three groups based on water level fluctuations and distance from the main flowing stream (see above) is globally consistent with the chemical compositions of the groundwater and their variations through time. All sample compositions are dominated by alkalinity for anions and by calcium-magnesium-sodium for cations. 


\begin{tabular}{|c|c|c|c|c|}
\hline & Well & $\begin{array}{c}\text { EC } \\
(\mu \mathrm{S} / \mathrm{cm})\end{array}$ & $\begin{array}{l}\text { Chloride } \\
(\mu \mathrm{mol} / \mathrm{l})\end{array}$ & $\begin{array}{c}\text { Alkalinity } \\
(\mu \mathrm{eq} / \mathrm{l})\end{array}$ \\
\hline \multirow{3}{*}{ 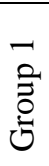 } & P3 & 835 & 913 & 6045 \\
\hline & P5 & 670 & 528 & 6250 \\
\hline & P6 & 935 & 450 & 6320 \\
\hline \multirow{5}{*}{$\begin{array}{l}N \\
\text { Oे } \\
\text { जे }\end{array}$} & P8 & 670 & 303 & 6935 \\
\hline & P9 & 450 & 327 & 4230 \\
\hline & P10 & 640 & 477 & 5020 \\
\hline & P12 & 274 & 201 & 2500 \\
\hline & P13 & 364 & 164 & 3570 \\
\hline \multirow{3}{*}{$\begin{array}{l}\text { m } \\
\text { 亏े } \\
\text { oे }\end{array}$} & $\mathrm{P} 1$ & 244 & 114 & 2180 \\
\hline & P7 & 573 & 137 & 5270 \\
\hline & P11 & 299 & 98 & 3417 \\
\hline
\end{tabular}

Table 2: mean EC, chloride content and alkalinity of sampled groundwater

Waters of group 1 (P3, P5 and P6) are relatively concentrated, with mean electrical conductivity (EC) ranging from $670 \mu \mathrm{S} / \mathrm{cm}$ in $\mathrm{P} 5$ to $935 \mu \mathrm{S} / \mathrm{cm}$ in $\mathrm{P} 6$, and mean $\mathrm{Cl}$ concentrations of $913 \mu \mathrm{mol} / 1$ in P3, $528 \mu \mathrm{mol} / 1$ in P5 and $450 \mu \mathrm{mol} / 1$ in P6. Calcium and Magnesium represent 80 to $90 \%$ of the cationic charge in this group. Chemical fluctuations due to vertical flows in wells P3 and P6 have been observed. The chemical composition of well P5 is stable over the monitoring period as illustrated in Figure 6a.

Waters of group 2 are on average less concentrated than those of group 1. Mean EC ranges from $274 \mu \mathrm{S} / \mathrm{cm}$ in $\mathrm{P} 12$ to $670 \mu \mathrm{S} / \mathrm{cm}$ in P8. Mean $\mathrm{Cl}$ concentrations are $303 \mu \mathrm{mol} / \mathrm{l}$ in P8, $327 \mu \mathrm{mol} / 1$ in $\mathrm{P} 9,477 \mu \mathrm{mol} / 1$ in $\mathrm{P} 10$ and $164 \mu \mathrm{mol} / 1$ in $\mathrm{P} 13$. Chlorine concentrations are sensitive to seasons, with dilutions during monsoon and concentrations during dry seasons. Depending on wells the proportion of Calcium and Magnesium range between 60 and $90 \%$.

Waters of group 3 (P1, P7 and P11) are the most diluted, with mean EC ranging from 244 to $573 \mu \mathrm{S} / \mathrm{cm}$, mean $\mathrm{Cl}$ concentrations from 114 to $137 \mu \mathrm{mol} / \mathrm{l}$ and mean alkalinity from 2180 to $5270 \mu \mathrm{eq} / 1$ in P1 and P7, respectively. The whole chemical composition of these wells is also a variable throughout the year with well-marked concentration during dry seasons in 2004 and 2006 (Figure 6c). Chlorine concentrations vary from 62 to $360 \mu \mathrm{mol} / 1$ in P1, from 33 to 251 in P7 and from 29 to 450 in P11, EC from 151 to $461 \mu \mathrm{S} / \mathrm{cm}$ in P1, from 161 to $716 \mu \mathrm{S} / \mathrm{cm}$ in $\mathrm{P} 7$ and from 100 to $783 \mu \mathrm{S} / \mathrm{cm}$ in P11. Calcium and Magnesium represent 80 to $95 \%$ of the cationic charge in this group. 


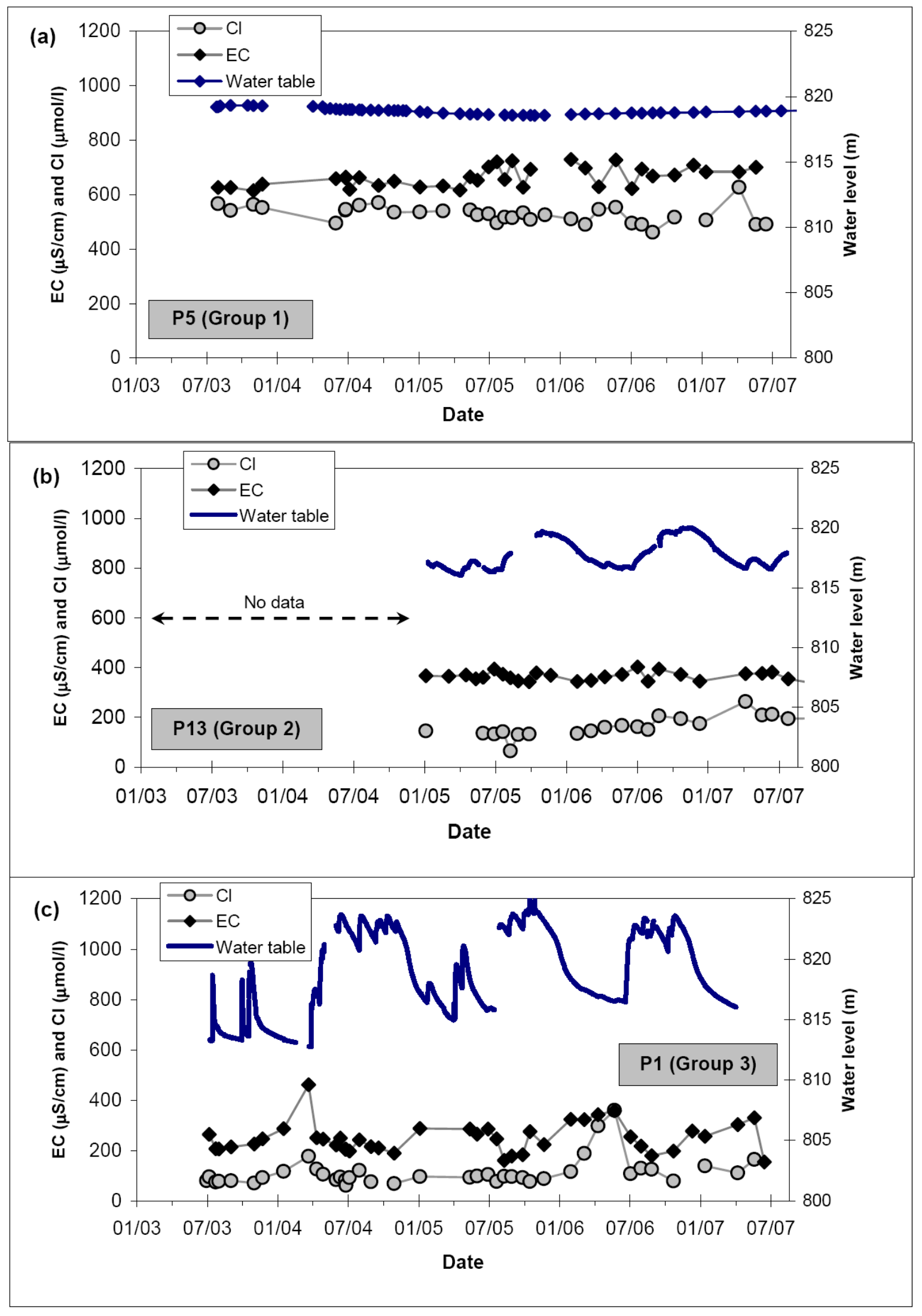

Figure 6: electrical conductivity $(E C)$, chloride content and water table elevation in monitoring wells P5 (a), P13 (b) and P1 (c). *Well P13 has been drilled in January 2005. 


\section{Discussion}

\subsection{Direct, localized and indirect recharges}

The chloride fluxes are used in equation (2) from CMB method to calculate the recharge rates using the average chloride content in each observation well and weighted averages chloride content in precipitation and runoff. The obtained values at the various monitoring wells range from 27 to $250 \mathrm{~mm} / \mathrm{year}$ (

\begin{tabular}{ccccc}
\hline Group & Well & $\begin{array}{c}\boldsymbol{C l}_{\boldsymbol{G} \boldsymbol{W}} \\
(\mu \mathrm{mol} / \mathrm{l})\end{array}$ & $\begin{array}{c}\boldsymbol{R} \\
(\mathrm{mm} / \text { year })\end{array}$ & $\begin{array}{c}\boldsymbol{R}_{\boldsymbol{i}}{ }^{\mathbf{1}} \\
(\mathrm{mm} / \text { year })\end{array}$ \\
\hline \multirow{3}{*}{ Group 1 } & P3 ${ }^{2}$ & $913 \pm 46$ & $27 \pm 5$ & $0 \pm 14$ \\
& $\mathrm{P} 5$ & $528 \pm 26$ & $47 \pm 9$ & $0 \pm 18$ \\
& $\mathrm{P}^{2}$ & $450 \pm 22$ & $55 \pm 11$ & $0 \pm 20$ \\
\hline \multirow{3}{*}{ Group 2 } & P2 & $533 \pm 27$ & $46 \pm 9$ & $0 \pm 18$ \\
& P10 & $477 \pm 24$ & $52 \pm 10$ & $0 \pm 19$ \\
& P9 & $327 \pm 16$ & $75 \pm 15$ & $30 \pm 24$ \\
& P8 & $303 \pm 15$ & $81 \pm 16$ & $36 \pm 40$ \\
& P12 & $202 \pm 10$ & $122 \pm 24$ & $77 \pm 33$ \\
Group 3 & P13 & $164 \pm 8$ & $150 \pm 30$ & $105 \pm 39$ \\
\hline & P7 & $137 \pm 7$ & $178 \pm 35$ & $133 \pm 44$ \\
& P1 & $114 \pm 6$ & $215 \pm 43$ & $170 \pm 52$ \\
& P11 & $98 \pm 5$ & $250 \pm 50$ & $205 \pm 59$ \\
\hline
\end{tabular}

Table 3). According to the most probable changes in groundwater flow directions, the chloride content fluctuates with time and characterizes mixed groundwater from various recharge areas. Therefore, in wells of group 3 and a part of group 2 (wells P8, P9 and P12), the estimated recharge corresponds to a yearly average on groundwater flowing at the sampled point. The values of total recharge estimated by CMB method at these sites do not correspond necessarily to recharge which happened through the unsaturated zone above the sampled water table.

\begin{tabular}{ccccc}
\hline Group & Well & $\begin{array}{c}\boldsymbol{C l}_{\boldsymbol{G W}} \\
(\mu \mathrm{mol} / \mathrm{l})\end{array}$ & $\begin{array}{c}\boldsymbol{R} \\
(\mathrm{mm} / \text { year })\end{array}$ & $\begin{array}{c}\boldsymbol{R}_{\boldsymbol{i}}{ }^{\mathbf{1}} \\
(\mathrm{mm} / \text { year })\end{array}$ \\
\hline \multirow{3}{*}{ Group 1 } & P3 & $913 \pm 46$ & $27 \pm 5$ & $0 \pm 14$ \\
& $\mathrm{P} 5$ & $528 \pm 26$ & $47 \pm 9$ & $0 \pm 18$ \\
& $\mathrm{P}^{2}$ & $450 \pm 22$ & $55 \pm 11$ & $0 \pm 20$ \\
\hline \multirow{3}{*}{ Group 2 } & P2 & $533 \pm 27$ & $46 \pm 9$ & $0 \pm 18$ \\
& P10 & $477 \pm 24$ & $52 \pm 10$ & $0 \pm 19$ \\
& P9 & $327 \pm 16$ & $75 \pm 15$ & $30 \pm 24$ \\
& P8 & $303 \pm 15$ & $81 \pm 16$ & $36 \pm 40$ \\
& P12 & $202 \pm 10$ & $122 \pm 24$ & $77 \pm 33$ \\
Group 3 & P13 & $164 \pm 8$ & $150 \pm 30$ & $105 \pm 39$ \\
\hline & P7 & $137 \pm 7$ & $178 \pm 35$ & $133 \pm 44$ \\
& P1 & $114 \pm 6$ & $215 \pm 43$ & $170 \pm 52$ \\
& P11 & $98 \pm 5$ & $250 \pm 50$ & $205 \pm 59$ \\
\hline
\end{tabular}

Table 3 : average chloride content in groundwater and computed recharge rate using CMB method (with $\left.P=1120 \mathrm{~mm} / \mathrm{yr} ; C l_{P}=24.6 \mu \mathrm{mol} / \mathrm{l} ; C l_{Q}=38 \mu \mathrm{mol} / \mathrm{l}\right)$ sorted according to increasing recharge rate. ${ }^{1}$ Indirect recharge component $R_{i}$ is estimated by difference between total recharge $R$ and assumed direct and localized recharge $R_{d, l}=45 \pm 9 \mathrm{~mm} /$ year. ${ }^{2}$ Chloride content in wells P2, P3 and P6 has been averaged on the first months after drilling in order to consider the pristine composition of groundwater not perturbed by vertical flows induced in the well.

The calculated recharge is increasing from group 1 to group 3. The wells P3, P5 and P6 (group 1) are located far away from the stream enough to be considered as not influenced by it: it is assumed that the indirect recharge is negligible $\left(R_{i}=0\right)$ at these wells. In such a 
fractured system, the localized recharge through cracks and fractures cannot be neglected specially during storm events (Shivanna et al., 2004). Therefore, the recharge estimated from group 1 can be considered as the reference for direct and localized recharge $\left(R_{d, l}=R_{d}+R_{l}\right)$ in the watershed: it ranges from 27 to $55 \mathrm{~mm} /$ year with an average of $45 \mathrm{~mm} / \mathrm{yr}$. The ratio $R_{d, l} / P$ of (direct and localized) recharge to rainfall at Mule Hole watershed is very low compared to values obtained for direct recharge only from tritium injection experiments in several geologically similar catchments located in non-forested areas of India (Rangarajan and Athavale, 2000). The application of the relationship proposed by these authors to the rainfall quantity observed on Mule Hole watershed $(P=1120 \mathrm{~mm} / \mathrm{yr})$ leads to an expected direct recharge value of about $150 \mathrm{~mm} / \mathrm{yr}$, much more than the observed one at wells from group 1 (Figure 7). The most probable cause of the observed deficit of direct recharge in this watershed is the high evapotranspiration by forest cover. This process occurs in the vadose zone as observed in many forested watersheds throughout the World (Zhang et al., 2001). It means that the forest consumes an excess of about $100 \mathrm{~mm} / \mathrm{yr}$ of actual evapotranspiration compared to non-forested case. This low rate of direct recharge at watershed scale is at the origin of the great depth of water table $(40.3 \mathrm{~m}$ at P5 and $38.4 \mathrm{~m}$ at P6) in this watershed, reversing the stream/aquifer interaction with losses from the stream. Such a lowering of water table through a reduction in the recharge of groundwater by forest cover has been already reported in the Karnataka region under Eucalyptus (Shiva and Bandyopadhyay, 1983).

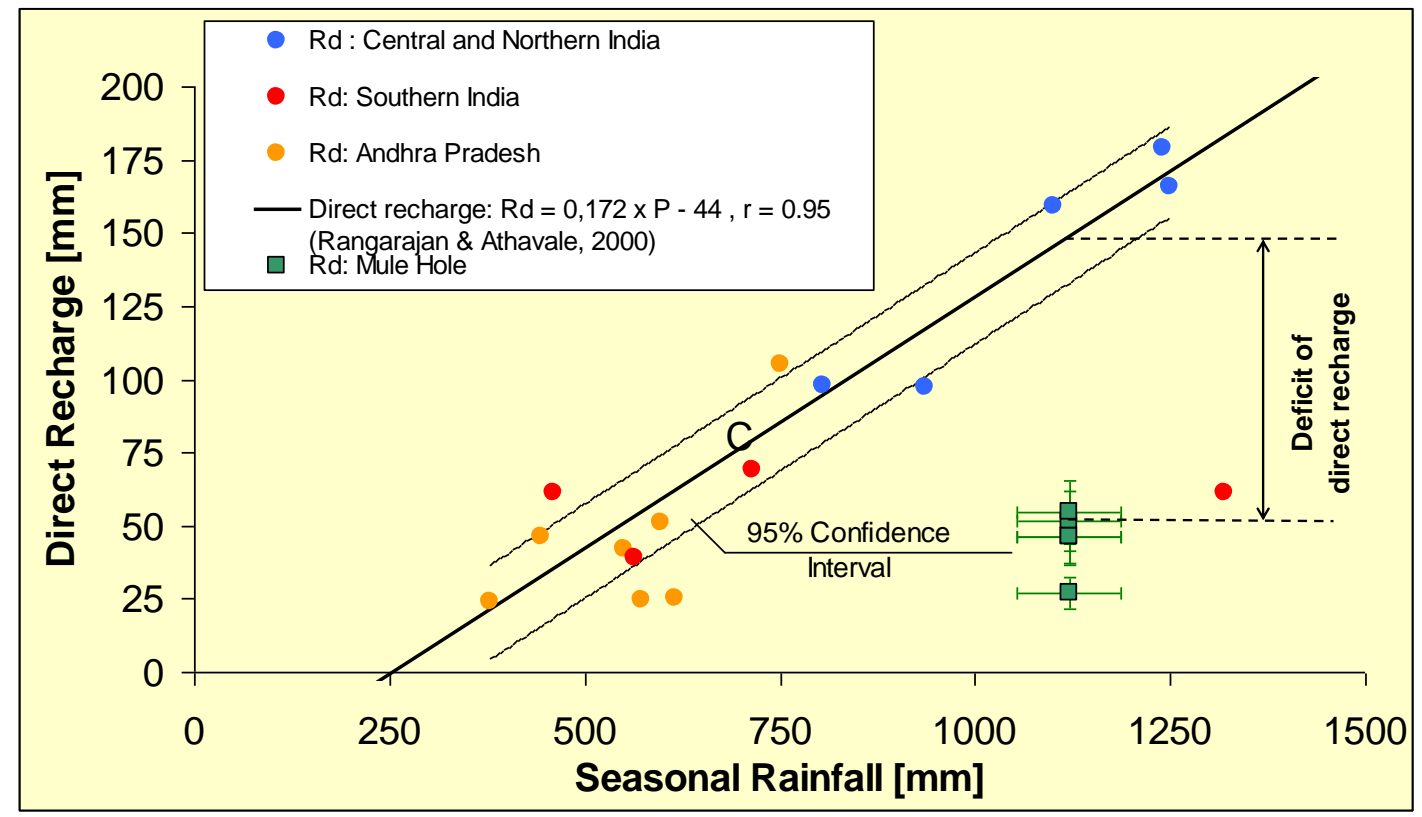

Figure 7: rainfall - direct recharge in granite and gneiss. Andhra-Pradesh, Southern, Central and Northern India direct recharge estimated using tritium injection (Rangarajan and Athavale, 2000; Sukhija et al., 1996). Comparison with direct recharge measured in Mule Hole watershed.

The total recharge to the groundwater in areas very close to the stream (P1, P7 and P11, Figure 8b) ranges from 180 to $250 \mathrm{~mm} / \mathrm{yr}$ in monitoring wells from group 3. This total recharge corresponds to the addition of direct recharge from rainfall diffuse percolation, localized recharge from percolation through cracks and joints and indirect recharge from the stream. Intermediary values $(120-150 \mathrm{~mm} / \mathrm{yr})$ at P12 and P13 in the vicinity (200 meters) of the stream show an influence of indirect recharge (group 2). Wells located on the Northern bank of the stream are characterized by direct and localized recharge only (P2, P3 and P10) or very low indirect recharge (P8 and P9). This is consistent with low water table fluctuations at these points (Figure 8a) and suggests the existence of an asymmetry in groundwater flows 
from the stream axis. The water received from indirect recharge should mostly flow to the South as suggested by Figure 8a.

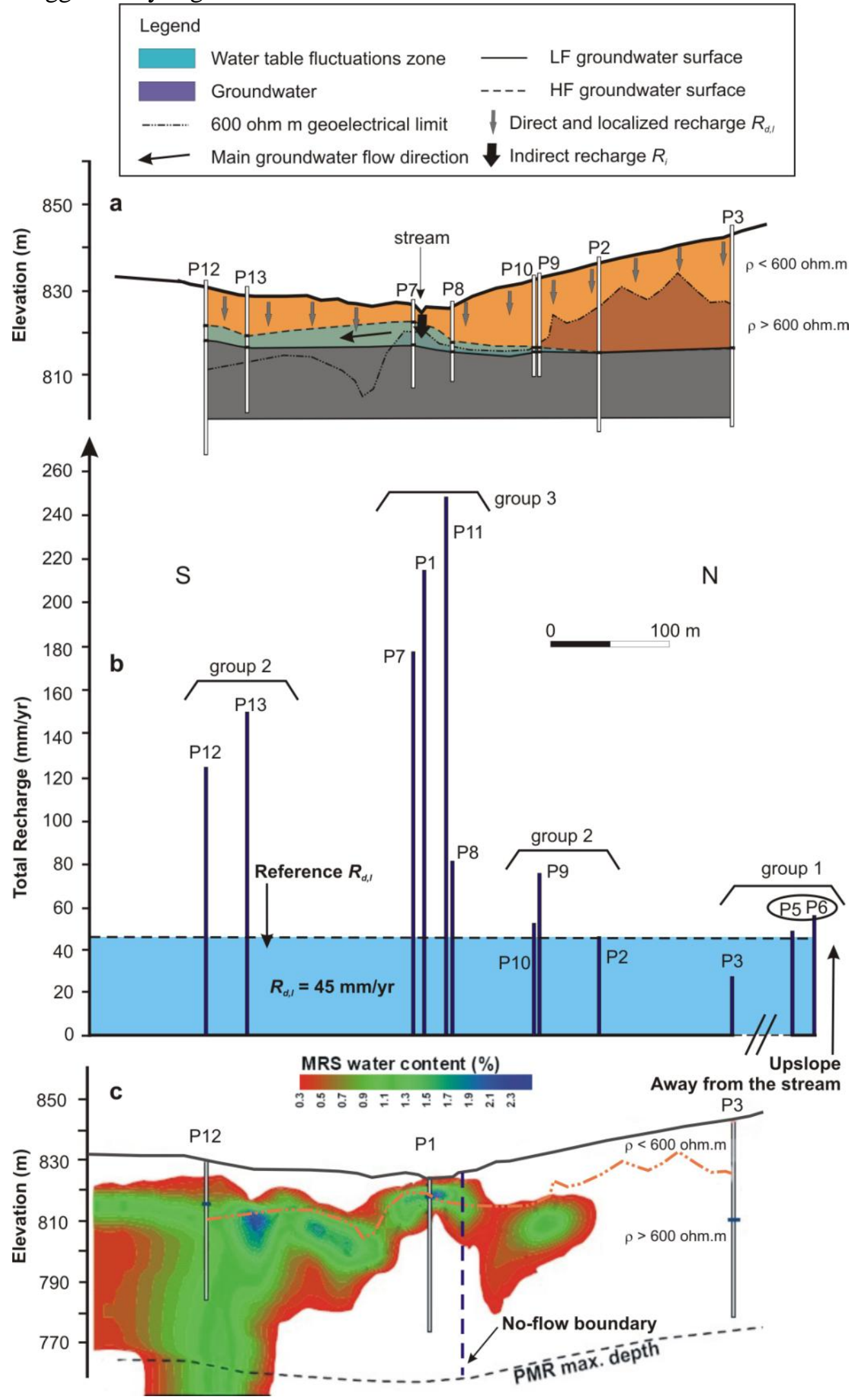

Figure 8: Combination of the approaches. (a) Cross section of the experimental site with water table fluctuations (LF: pre-monsoon low flow in June 2006; HF: post-monsoon high flow in December 2005), Observation wells P1 and P11 are not figured for clarity reason. (b) Recharge estimated using CMB 
method. (c) Water content from geophysical measurements (MRS) and no-flow boundary from hydraulic tests.

Descloitres et al. (2008) compared MRS and ERT measurements carried out at the outlet of the watershed before and during the 2004 monsoon (Figure 1). They concluded that a seasonal indirect recharge occurs under the stream. Moreover, a cross section of MRS water content obtained from the interpretation of 15 soundings located at the outlet of the watershed (Figure 8c) has been proposed by Legchenko et al. (2006). The MRS have been carried out in November 2004 during the monsoon. The water content distribution indicates that the saturated water reservoir is strongly dissymmetric and mainly located on the south bank of the stream. MRS water content ranges between $0.5 \%$ (threshold value for the used device) and $2 \%$.

Hydraulic tests have been carried out in several boreholes of the watershed in 2006. The interpretation of the 18 hours pumping tests conducted in P1 and monitored in P1, P7 and P8 indicated a no-flow boundary (Figure $8 \mathrm{~b}$ ). This boundary is located north of the stream and is orientated parallel to the geological structures, i.e. N70 ${ }^{\circ}$. It acts as an underground barrier and is probably caused by an uplift of the bedrock. This is the reason why indirect recharge under the stream can not flow easily to the north. Such underground no-flow boundary is not clearly identified when interpreting the pumping test of 50 hours conducted in the south of the stream (pumping in P12 and monitored in P12 and P13).

Assuming $R_{d, l}=45 \pm 9 \mathrm{~mm} /$ year, the indirect recharge due to infiltration from the stream may be estimated (

\begin{tabular}{ccccc}
\hline Group & Well & $\begin{array}{c}\boldsymbol{C l}_{\boldsymbol{G W}} \\
(\mu \mathrm{mol} / \mathrm{l})\end{array}$ & $\begin{array}{c}\boldsymbol{R} \\
(\mathrm{mm} / \text { year })\end{array}$ & $\begin{array}{c}\boldsymbol{R}_{\boldsymbol{i}}^{\mathbf{1}} \\
(\mathrm{mm} / \text { year })\end{array}$ \\
\hline \multirow{3}{*}{ Group 1 } & P3 & $913 \pm 46$ & $27 \pm 5$ & $0 \pm 14$ \\
& P5 & $528 \pm 26$ & $47 \pm 9$ & $0 \pm 18$ \\
& P6 & $450 \pm 22$ & $55 \pm 11$ & $0 \pm 20$ \\
\hline Group 2 & P2 $^{2}$ & $533 \pm 27$ & $46 \pm 9$ & $0 \pm 18$ \\
& P10 & $477 \pm 24$ & $52 \pm 10$ & $0 \pm 19$ \\
& P9 & $327 \pm 16$ & $75 \pm 15$ & $30 \pm 24$ \\
& P8 & $303 \pm 15$ & $81 \pm 16$ & $36 \pm 40$ \\
& P12 & $202 \pm 10$ & $122 \pm 24$ & $77 \pm 33$ \\
& P13 & $164 \pm 8$ & $150 \pm 30$ & $105 \pm 39$ \\
\hline \multirow{2}{*}{ Group 3 } & P7 & $137 \pm 7$ & $178 \pm 35$ & $133 \pm 44$ \\
& P1 & $114 \pm 6$ & $215 \pm 43$ & $170 \pm 52$ \\
& P11 & $98 \pm 5$ & $250 \pm 50$ & $205 \pm 59$ \\
\hline
\end{tabular}

Table 3) by:

$$
R_{i}=R-R_{d, l}
$$

The indirect recharge fluctuates between 0 and $200 \mathrm{~mm} / \mathrm{yr}$. These values are representative of local areas close to the sampled wells and the stream, they cannot be up-scaled at the entire watershed area at which scale the indirect recharge, estimated below, is much less.

\subsection{Recharges, specific yield and water table fluctuations}

The water table fluctuation (WTF) method is based on the assumption that groundwater level change during a given period can be attributed to groundwater inflow minus outflow during the same period. In the Mule Hole watershed, the aquifer being disconnected, there is no baseflow to the stream. The main groundwater flow components are therefore the recharge $R$ as input and groundwater outflow $Q_{\alpha}$ below the outlet. The method has been applied twice, during recharge (monsoon) and dry periods.

Modified from (Healy and Cook, 2002), the following equation can be applied for the monsoon (wet) period: 


$$
R-Q_{\alpha, w e t}=S_{y} \Delta h_{\text {wet }}
$$

with $R$ the total recharge, $S_{y}$ the specific yield of the aquifer, $Q_{\alpha, \text { wet }}$ the groundwater outflow and $\Delta h_{\text {wet }}$ the water level fluctuation during the recharge (wet) period. Neglecting the recharge during the dry season, assuming that the outflow is equally distributed throughout the year between monsoon and dry periods $\left(Q_{\alpha, w e t}=Q_{\alpha, d r y}\right)$ and that the water table comes back every year to its initial level $\left(\Delta h_{T}=0\right)$, the yearly water balance equation becomes:

$$
R-2 Q_{\alpha, \text { wet }}=S_{y} \Delta h_{T}=0 \quad \text { and } \quad Q_{\alpha, \text { wet }}=R / 2
$$

For the recharge period, introducing (5) into (4) leads to:

$$
R / 2=S_{y} \Delta h_{\text {wet }}
$$

According to (6), the specific yield averaged on the experimental site can be determined from the slope of the linear regression between half the recharge and water table fluctuation during the wet period.

The method is best applied to shallow water tables that display sharp water-level rises and declines (Healy and Cook, 2002). Wells P5 and P6 where the aquifer is deep does not display sharp rise because wetting front tends to disperse over long distances. On the contrary, the method can be applied to wells close to the stream where the water table is shallow and comes back every year to the initial level (wells P1, P7, P8, P11, P12 and P13). The recharge estimated using the CMB method is compared to water level fluctuations in these wells. The water table increases during six months-monsoon periods have been calculated yearly from 2003 to 2006. The average of the four years has been considered at each monitoring well. On the diagram of half recharge versus water level increase (Figure 9), the trend is quite linear with an increase of water level fluctuation with recharge.

According to equation (6), the slope of the linear regression between the dots on the diagram corresponds to the specific yield $S_{y}$ of the aquifer. The obtained specific yield is $0.015 \pm 0.003$ which is comparable to the MRS (Magnetic Resonance Sounding) water content (0.005 0.02) obtained from 1D-soundings in the shallow part of the aquifer (Legchenko et al., 2006). This value is also very close to values obtained from water level fluctuations in a similar fractured crystalline aquifer in India (Maréchal et al., 2006).

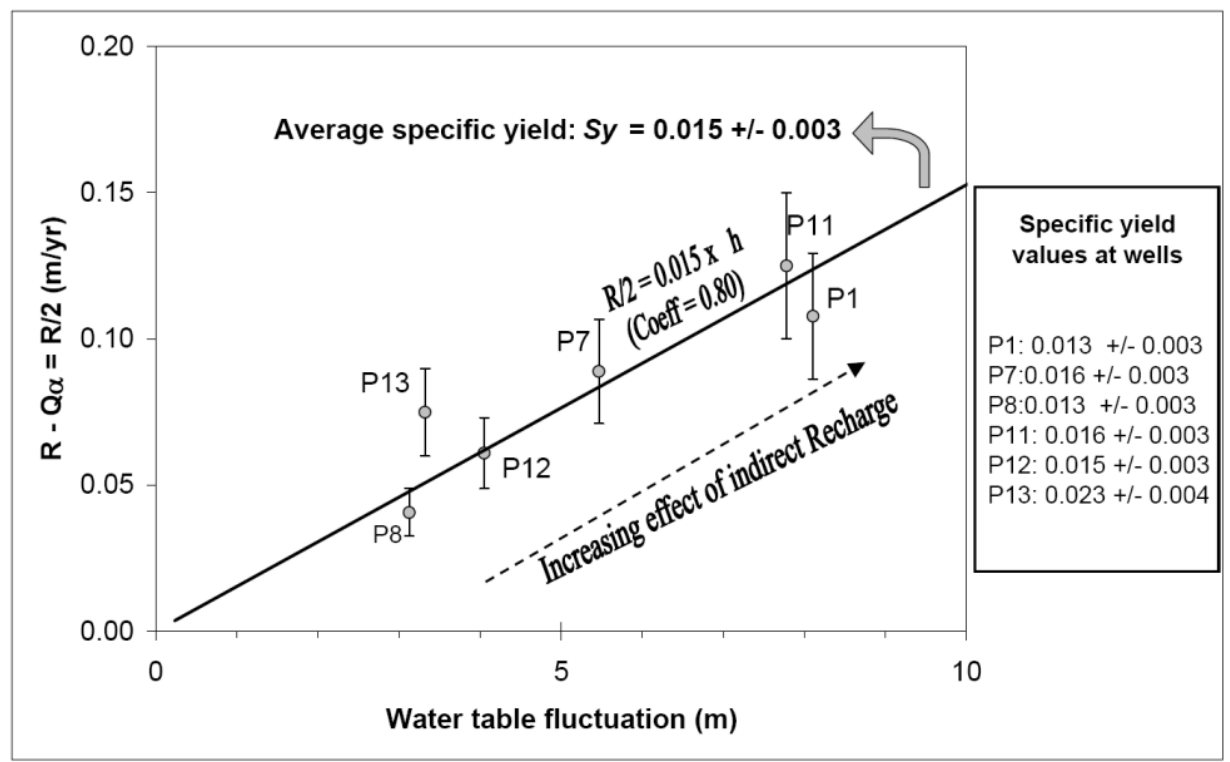


Figure 9: water budget during the recharge period as a function of observed water table fluctuations in monitoring wells. The slope of the straight line corresponds to the average specific yield of the aquifer (= 0.015). Individual values at wells are also calculated using equation (6).

\subsection{Effect of recharge on groundwater chemistry}

The Electrical Conductivity (EC) referred to $20^{\circ} \mathrm{C}$ is used in order to monitor the evolution of the chemical content of groundwater in observation wells (Figure 10a).

The short delay of reaction - a few hours - of the water table at wells from group 3 (Figure 4 and Figure 5) after stream runoff indicates that indirect recharge is a fast process. Therefore, the water chemistry of indirect recharge can be assumed to be not modified by evapotranspiration and water-rock interaction processes during its transit through the unsaturated zone as these delays are very short. As a result, the chemical content of indirect recharge reaching the aquifer can be assumed to be the same than runoff $\left(E C_{\text {moy }}=70 \mu \mathrm{S} / \mathrm{cm}\right)$.

The direct recharge is a longer process due to the average thickness of the unsaturated zone on the watershed. The water undergoes evapotranspiration and water-rock interaction during its vertical diffuse flow. Well P6 (Figure 10) is characterized by highest $\left(E C_{m o y}=910 \mu \mathrm{S} / \mathrm{cm}\right)$ and quite stable $E C(\sigma=49$ $\mu \mathrm{S} / \mathrm{cm})$. In the absence of indirect recharge there (

\begin{tabular}{ccccc}
\hline Group & Well & $\begin{array}{c}\boldsymbol{C l}_{\boldsymbol{G W}} \\
(\mu \mathrm{mol} / \mathrm{l})\end{array}$ & $\begin{array}{c}\boldsymbol{R} \\
(\mathrm{mm} / \text { year })\end{array}$ & $\begin{array}{c}\boldsymbol{R}_{\boldsymbol{i}}{ }^{\mathbf{1}} \\
(\mathrm{mm} / \text { year })\end{array}$ \\
\hline \multirow{3}{*}{ Group 1 } & P3 ${ }^{2}$ & $913 \pm 46$ & $27 \pm 5$ & $0 \pm 14$ \\
& P5 & $528 \pm 26$ & $47 \pm 9$ & $0 \pm 18$ \\
& P6 ${ }^{2}$ & $450 \pm 22$ & $55 \pm 11$ & $0 \pm 20$ \\
\hline \multirow{5}{*}{ Group 2 } & P2 & $533 \pm 27$ & $46 \pm 9$ & $0 \pm 18$ \\
& P10 & $477 \pm 24$ & $52 \pm 10$ & $0 \pm 19$ \\
& P9 & $327 \pm 16$ & $75 \pm 15$ & $30 \pm 24$ \\
& P8 & $303 \pm 15$ & $81 \pm 16$ & $36 \pm 40$ \\
& P12 & $202 \pm 10$ & $122 \pm 24$ & $77 \pm 33$ \\
Group 3 & P13 & $164 \pm 8$ & $150 \pm 30$ & $105 \pm 39$ \\
\hline & P7 & $137 \pm 7$ & $178 \pm 35$ & $133 \pm 44$ \\
& P1 & $114 \pm 6$ & $215 \pm 43$ & $170 \pm 52$ \\
& P11 & $98 \pm 5$ & $250 \pm 50$ & $205 \pm 59$ \\
\hline
\end{tabular}

Table 3), the EC at P6 can be considered as the reference $E C$ for aquifer recharged by direct recharge only.

$E C_{m o y}$ at $\mathrm{P} 1$ is quite low $(250 \mu \mathrm{S} / \mathrm{cm})$ and varies with time: it increases during no-flow periods at the stream and decreases after dilution by water infiltration (indirect recharge) from the stream. Dilution periods are outlined in grey on Figure 10. Considering both existing endmembers: surface water in the stream $\left(E C_{\text {moy }}=70 \mu \mathrm{S} / \mathrm{cm}\right)$ and groundwater $\left(E C_{\text {moy }}=910\right.$ $\mu \mathrm{S} / \mathrm{cm}$ ), their respective contributions can be easily estimated using the mixing theory at P1. With a total average of $250 \mu \mathrm{S} / \mathrm{cm}$, the groundwater at P1 is constituted by $20 \%$ of reference groundwater and $80 \%$ of stream water. The contribution of stream water increases to $90 \%$ during the monsoon (Figure 10). Periods of concentration in P1 groundwater are characterized by the total absence of runoff despite possible occurrence of rainfall. During rainy periods (beginning and end of monsoons), the increase of concentration is linked to the percolation of rainfall (highly concentrated direct recharge). During dry season, the increase is probably due to water-rock interaction (weathering processes as observed by (Braun et al., 2008). The absence of runoff during these periods induces no arrival of diluted surface water. This decrease of stream water contribution induces an increase of groundwater concentration. As a summary, the chemistry of water at well P1 results from the combination of three processes: concentration process by direct recharge during rainy events, concentration process by waterrock interaction during the whole year and dilution process by indirect recharge during flow periods at the stream. 
The chemical content of groundwater at P8 is comprised between P1 and P6. During the monsoon, it is closer to P1 because of the groundwater mound and flows from P1 to P8. During dry period, P8 chemistry tends to P6 because the mound has disappeared and the groundwater at $\mathrm{P} 8$ tends to the groundwater end-member.

The groundwater at P13 is quite stable with a mean EC close to P1. It shows the effect of indirect recharge with an average stream contribution of about $65 \%$. The groundwater flow path between the stream and P13 acts as a buffer which absorbs the chemical fluctuations during monsoon.

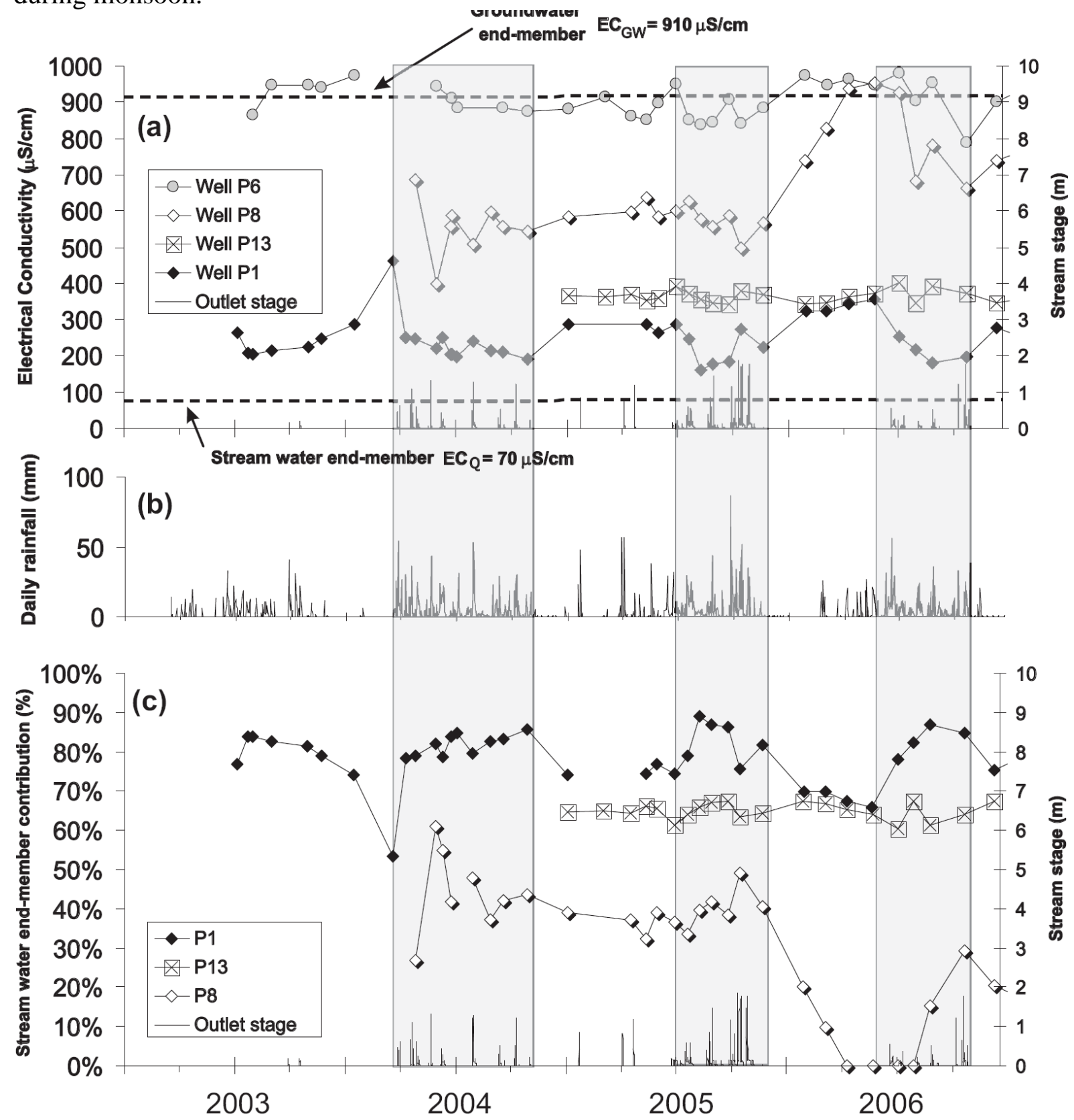

Figure 10: (a) electrical conductivity and stream stage evolution in wells P6 (group 1), P8 (group 2), P13 and P1 (group 3) during the monitoring period; (b) daily rainfall; (c) contribution of stream water endmember to aquifer chemistry. In grey: dilution periods. 


\subsection{Groundwater mound and flows}

To better understand how the aquifer responds to indirect recharge from the Mule hole stream, the water level fluctuations at monitoring wells have been modeled using the following analytical solution (Kresic, 1997):

$$
\Delta h(x, t)=\Delta h_{0} R\left(\frac{x}{\sqrt{4 D t}}\right)
$$

where $\Delta h_{0}=b t$ is the linear water level rise under the stream (at $\left.x=0\right)(\mathrm{m}), b$ is the rate of water level rise $(\mathrm{m} / \mathrm{s}), t$ is the time since the initial head change (seconds), $x$ is the distance between the monitoring well and the stream (or a reference monitoring well close to the stream), $D$ is the diffusivity of the aquifer $\left(\mathrm{m}^{2} / \mathrm{s}\right)$, and $R(\lambda)=4 i^{2} \operatorname{erfc}(\lambda)$ with $\operatorname{erfc}(\lambda)$ the complementary error function.

The initial change in head is measured at a monitoring well close to the stream, i.e. the well P7. It corresponds to the difference between the water table elevation at P7 before the onset and after a period of duration $t$. The water level fluctuation at $\mathrm{P} 7$, which is at the origin of the mound is not linear as suggested by Figure 11. Therefore equation (7) has been implemented in superposition in order to consider the complex water level change at P7 due to indirect recharge. Considering that water level fluctuations at P7 are linear at a daily time step, the change in head in the aquifer can be written

$$
\Delta h\left(x, t_{N}\right)=\sum_{i=1}^{N}\left[\Delta h\left(0, t_{i}\right)-\Delta h\left(0, t_{i-1}\right)\right] R\left(\frac{x}{\sqrt{4 D\left(t_{N}-t_{i-1}\right)}}\right)
$$

with $t_{0}=0$.

The groundwater mound south of the stream has been analyzed. Equation (8) has been applied to the couple of wells P7-P13 in April-May 2005 on a short ( $N=3$ days) and a long duration $(N=35$ days) basis. The model has been matched to measurements following a trials/errors process. The best fit of the modeled head change at P13 $(x=153 \mathrm{~m})$ during 3 days leads to a hydraulic diffusivity $D=0.04 \mathrm{~m}^{2} / \mathrm{s}$. This value can be compared with the diffusivity of 0.1 $\mathrm{m}^{2} / \mathrm{s}$ obtained as an average in a similar fractured crystalline aquifer (Maréchal et al., 2004). The same value $\left(0.04 \mathrm{~m}^{2} / \mathrm{s}\right)$ has been obtained during a pumping test of 25 hours duration between P12 and P13. For a longer duration, the matching of modeling curve with measurements on 35 days is not perfect probably because of heterogeneity effects in such a fractured system (Figure 11). The obtained value is $0.018 \mathrm{~m}^{2} / \mathrm{s}$. It is assumed that lateral heterogeneity in the aquifer is at the origin of the observed decrease of diffusivity with the duration and the radius of influence of the test. The relative good matching of model with measurements at P7 using reasonable hydrodynamic parameters consistent with pumping tests, shows that water table fluctuations at P13 can be explained by the groundwater mound propagation from P7 through the aquifer. This is consistent with the intermediary chemistry of the aquifer at P13. 


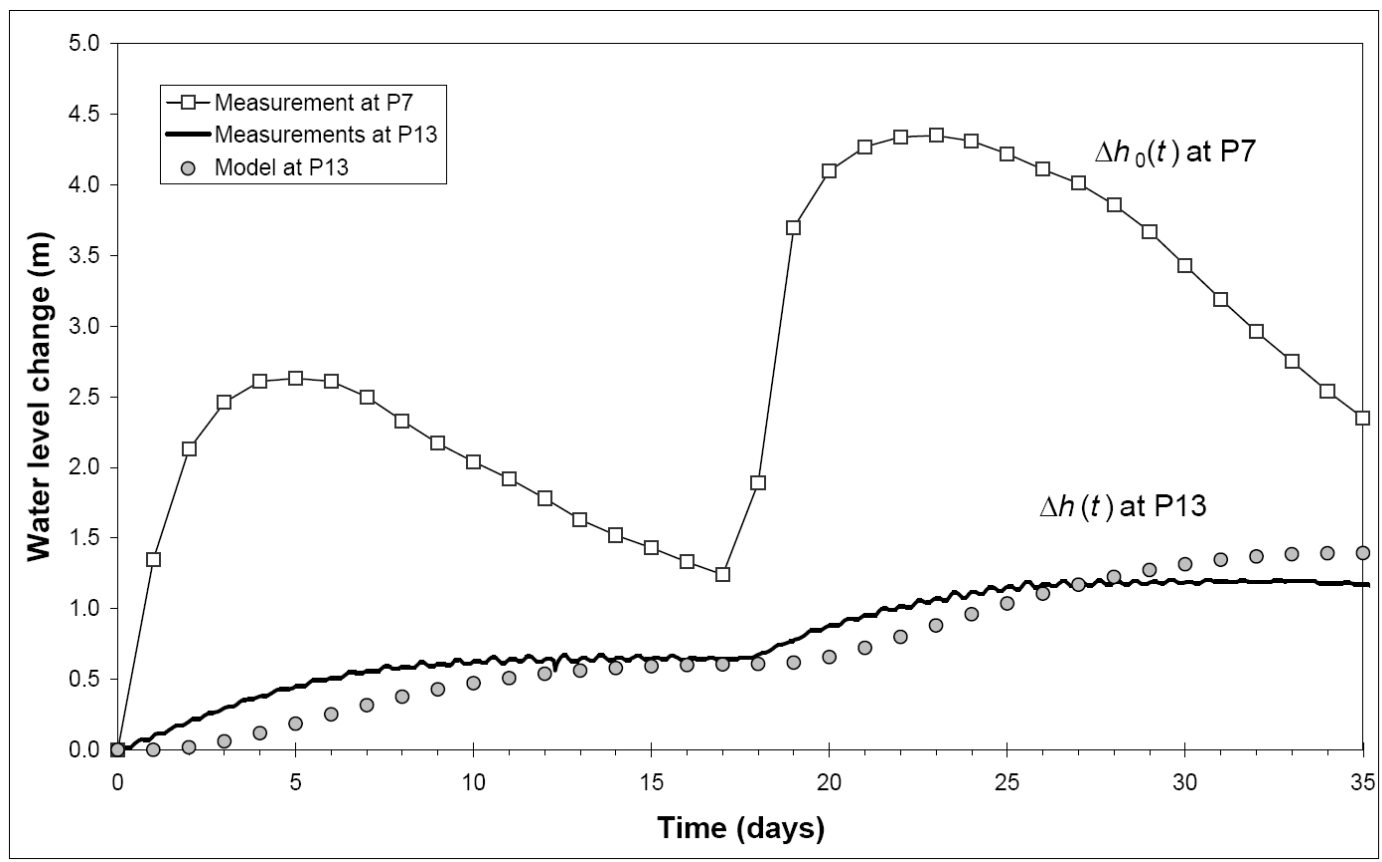

Figure 11: water level rise at monitoring wells P7 and P13 after $10^{\text {th }}$ April runoff event (period of monitoring from $11^{\text {th }}$ April to $15^{\text {th }}$ May 2005)

One way to assess the water seepage from the stream is to consider that this quantity of water is flowing in the aquifer laterally towards the South. The flow in the aquifer can be obtained applying Darcy law between wells P7 and P13:

$$
q(t)=T \frac{h_{P 7}(t)-h_{P 13}(t)}{x}
$$

with $q(t)$ the linear flow perpendicular to the stream $\left(\mathrm{m}^{2} / \mathrm{s}\right)$ and $\frac{h_{P 7}(t)-h_{P 13}(t)}{x}$ the hydraulic gradient (-) between P7 and P13.

The average transmissivity $T=1.6 \times 10^{-4} \mathrm{~m}^{2} / \mathrm{s}$ has been obtained by pumping tests in wells $\mathrm{P} 7$ and $\mathrm{P} 13$; this value is quite typical for the weathered-fissured part of a hard-rock aquifer (Maréchal et al., 2004). The hydraulic gradient and the flow rate between P7 and P13 have been hourly computed during 2006 applying equation (9). The total amount of linear flow is about $3 \mathrm{l} / \mathrm{s} / \mathrm{m}$, which corresponds to about $15 \mathrm{~mm} / \mathrm{year}$ at the watershed scale, for a reference surface area of $4.1 \mathrm{~km}^{2}$ and for a $1000 \mathrm{~m}$-long infiltrating stream.

The low-lying area, occupying the lower part of the slope and the flat valley bottoms are mainly covered by black soils to which $2: 1$ clays (smectite - montmorillonite) provide vertic properties and low permeability (Barbiero et al., 2007). Therefore, water losses will take place where the stream flows through red soils or on the bedrock itself. Considering about 2000 meters of stream length on that kind of permeable material, the total rate of indirect recharge at the watershed scale is about $30 \mathrm{~mm} / \mathrm{yr}$. This amount is small but it must be related to the small number of flowing days in this ephemeral stream.

The low total recharge rate induces : (i) a lowering of the water table and (ii) a water table which is recharge-controlled and not topography-controlled (Haitjema and Mitchell-Bruker, 2005). As a result, the water table is most probably not a subdued replica of the local topography and the groundwater basin boundaries do not coincide with the surface watershed as confirmed by groundwater outflow below the outlet. 


\subsection{Water budget and forest evapotranspiration}

Actual evapotranspiration (ET) is a major component of the water cycle which is hardly measurable specially in forested watershed. In case other components of water cycle are known, actual evapotranspiration can be estimated as the residual of the catchment water balance (Bosch and Hewlett, 1982):

$$
E T=P-R_{d, l}-R_{i}-Q-\Delta S
$$

where $E T$ is evapotranspiration, $P$ is precipitation, $Q$ is surface runoff measured as stream flow, $R_{d, l}$ is direct and localized recharge to groundwater, $R_{i}$ is indirect recharge and $\Delta S$ is the change in soil water storage.

Usually, this technique for evapotranspiration estimate faces a lack of information on the recharge component. Using the recharges here above estimated and neglecting the soil water storage yearly fluctuations at the watershed scale, equation (10) is used to estimate the annual actual evapotranspiration in the Mule Hole watershed (Table 4).

\begin{tabular}{cccccc}
\hline Year & $\begin{array}{c}P \\
(\mathrm{~mm} / \mathrm{yr})\end{array}$ & $\begin{array}{c}R_{d, l} \\
(\mathrm{~mm} / \mathrm{yr})\end{array}$ & $\begin{array}{c}R_{i} \\
(\mathrm{~mm} / \mathrm{yr})\end{array}$ & $\begin{array}{c}Q \\
(\mathrm{~mm} / \mathrm{yr})\end{array}$ & $\begin{array}{c}E T \\
(\mathrm{~mm} / \mathrm{yr})\end{array}$ \\
\hline 2004 & $1216 \pm 73$ & & & $66 \pm 13$ & $1075 \pm 110$ \\
2005 & $1434 \pm 86$ & $45 \pm 9$ & $30 \pm 15$ & $196 \pm 39$ & $1163 \pm 150$ \\
2006 & $1170 \pm 70$ & & & $52 \pm 10$ & $1043 \pm 105$ \\
\hline
\end{tabular}

Table 4: values of the components of the water balance of the watershed from 2004 to $2006, E T$ is calculated using equation (10). The year 2003 is not considered as rainfall and runoff time series are not complete. ET during 2005 is most probably overestimated as soil water storage fluctuation could have been non negligible during this rainy year.

The annual evapotranspiration is directly related to the available water on the watershed and therefore limited by rainfall. The average ET on years characterized by a normal rainfall (2004 and 2006) is about $1050 \mathrm{~mm} / \mathrm{yr}$. The comparison of the evapotranspiration with other evergreen forests from the same region (Nilgiris, (Sharda et al., 1998)) and with the forested worldwide curve (Zhang et al., 2001) shows a good agreement (Figure 12), confirming the role of the vegetation on the water budget. In this forested watershed, the evapotranspiration represents about $87 \%$ of the rainfall: this very high actual evapotranspiration, close to the reference evapotranspiration for alfalfa $\left(E T_{r}=1205 \mathrm{~mm} / \mathrm{yr}\right)$ was unexpected in such a deciduous forest. It would require high crops coefficient throughout the year: despite the absence of rainfall during a long six months period, the great depth and extent of the roots of the trees would contribute to increase the transpiration by forest in deep soils during dry season (Calder, 1990; Nepstad et al., 1994). 


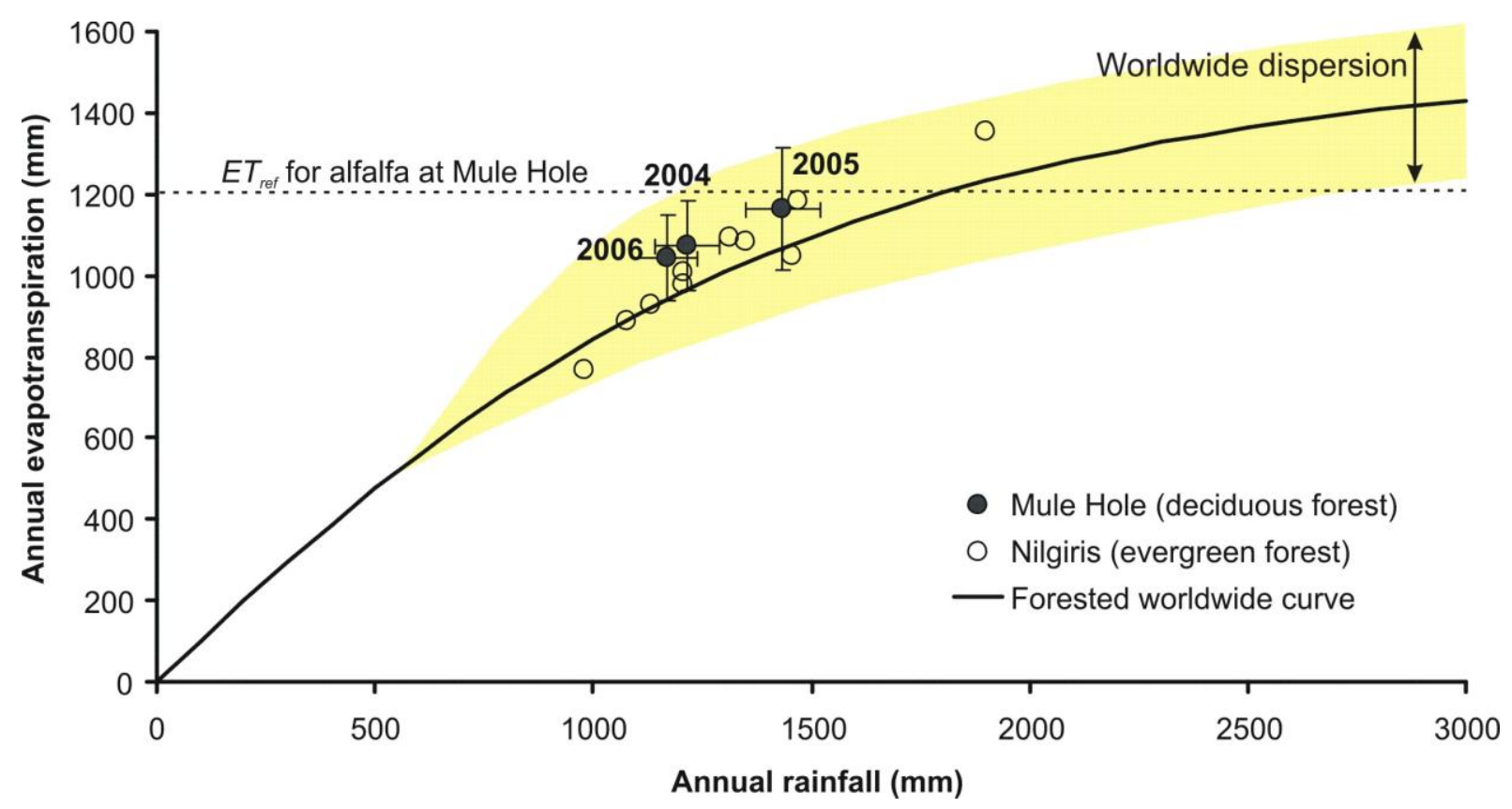

Figure 12: relationship between annual rainfall and evapotranspiration at Mule Hole watershed compared to Nilgiris watersheds and forest worldwide curve from (Zhang et al., 2001). The grey area represents the dispersion around the worldwide curve.

The error obtained on evapotranspiration is about $10 \%$ (Table 4), which is acceptable for a yearly water budget. The errors on recharge and evapotranspiration are mainly due to analytical errors on chloride content in waters (rainfall and groundwater). Additional uncertainties due to variable chloride content in rainfall would require a modeling approach to be quantified. An extensive monitoring of rainfall chloride content is necessary in order to minimize them.

\section{Conclusion}

A multidisciplinary approach consisting of chloride mass balance technique coupled with water table fluctuations study and groundwater flow analytical modeling leads to a rigorous estimate of direct, localized $\left(R_{d, l}=45 \mathrm{~mm} / \mathrm{yr}\right)$ and indirect recharge $\left(R_{i}=30 \mathrm{~mm} / \mathrm{yr}\right)$ rates to groundwater in a forested watershed. Complementary geophysical measurements and hydraulic tests respectively confirm and explain the dissymmetry of recharge around the stream axis. The low values of recharge rates imply an unexpected very high evapotranspiration rate by the deciduous forest cover in such a humid watershed where the evapotranspiration (and consequently the recharge) is controlled by both water availability and atmospheric demand. The forest impacts the rate of recharge of percolating water to the water table as deep tree roots abstract water from the unsaturated zone during the transpiration process. Such high values of actual evapotranspiration would require complementary studies on evapotranspiration rates to be confirmed. The resulting low recharge rate leads to a depleted water table which is disconnected from the surface stream. Therefore, the stream is highly ephemeral. While flowing, the stream infiltrates to the ground and indirect recharge takes place a few tens of days a year. In the absence of groundwater flow to the stream, the total recharge to groundwater flows as outflow under the outlet of the watershed. This implies that vegetation abstraction has modified the groundwater basin which is now different from surface watershed.

The chloride mass balance method emerges as a powerful technique for recharge estimate in forested watersheds which are pristine of human activity and chloride input. Chemical content in the aquifer results from dynamics of direct and indirect recharge rates. As a perspective, the 
modeling of chloride content in the aquifer is the next step in order to better understand the groundwater chemistry.

\section{Acknowledgments}

The Mule Hole basin is part of the ORE-BVET project (Observatoire de Recherche en Environnement - Bassin Versant Expérimentaux Tropicaux, www.orebvet.fr). Apart from the specific support from the French Institute of Research for Development (IRD), the Embassy of France in India and the Indian Institute of Science, our project benefited from funding from IRD and INSU/CNRS (Institut National des Sciences de l'Univers / Centre National de la Recherche Scientifique) through the French programmes ECCO-PNRH (Ecosphère Continentale: Processus et Modélisation - Programme National Recherche Hydrologique), EC2CO (Ecosphère Continentale et Côtière) and ACI-Eau. It is also funded by the IndoFrench programme IFCPAR (Indo-French Center for the Promotion of Advanced Research W-3000). The multidisciplinary research carried on the Mule Hole watershed began in 2002 under the control of the IFCWS (Indo-French Cell for Water Sciences), joint laboratory IISc/IRD. We thank the Karnataka Forest Department and the staff of the Bandipur National Park for all the facilities and support they provided. 


\section{References}

Alcalá, F.J. and Custodio, E., 2008. Atmospheric chloride deposition in continental Spain. Hydrological Processes, 22(18): 3636-3650.

Allen, R.G., Pruitt, W.O., Wright, J.L., Howell, T.A., Ventura, F., Snyder, R., Itenfisu, D., Steduto, P., Berengena, J., Baselga Yrisarry, J., Smith, M., Pereira, L.S., Raes, D., Perrier, A., Alves, I., Walter, I. and Elliott, R., 2006. A recommendation on standardized surface resitance for hourly calculation of reference ET0 by the FAO56 Penman-Montheit method. Agricultural Water Management, 81: 1-22.

Barbiero, L., Parate, H.R., Descloitres, M., Bost, A., Furian, S., Mohan Kumar, M.S., Kumar, C. and Braun, J.J., 2007. Using a structural approach to identify relationships between soil and erosion in a semi-humid forested area, South India. CATENA, 70(3): 313-329.

Bazuhair, A.S. and Wood, W.W., 1996. Chloride mass-balance method for estimating ground water recharge in arid areas: examples from western Saudi Arabia. Journal of Hydrology, 186(1-4): 153-159.

Bosch, J.M. and Hewlett, J.D., 1982. A review of catchment experiments to determine the effect of vegetation changes on water yield and evapotranspiration. Journal of Hydrology, 55(1-4): 3-23.

Braun, J.-J., Descloîtres, M., Riotte, J., Fleury, S., Laurent, B., Boeglin, J.-L., Violette, A., Lacarce, E., Ruiz, L., Sekhar, M., Mohan Kumar, M.S., Subrahmanian, S. and Dupré, B., 2008. Regolith mass balance inferred from combined mineralogical, geochemical and geophysical studies: Mule Hole gneissic watershed, South India. Geochimica et cosmochimica acta, accepted.

Bruijnzeel, L.A., 2004. Hydrological functions of tropical forests: not seeing the soil for the trees? Agriculture, Ecosystems \& Environment, 104(1): 185-228.

Calder, I.R., 1990. Evaporation in the Uplands. Wiley, New York, 148 pp.

de Vries, J.J. and Simmers, I., 2002. Groundwater recharge: an overview of processes and challenges. Hydrogeology Journal, 10: 5-17.

Descloitres, M., Ruiz, L., Sekhar, M., Legchenko, A., Braun, J.J., Mohan Kumar, M.S. and Subramanian, S., 2008. Characterization of seasonal local recharge using electrical resistivity tomography and magnetic resonance sounding. Hydrological Processes, 22(3): 384-394.

Dettinger, M.D., 1989. Reconnaissance estimates of natural recharge to desert basins in Nevada, U.S.A., by using chloride-balance calculations. Journal of Hydrology, 106(1-2): 55-78.

Dewandel, B., Lachassagne, P., Wyns, R., Marechal, J.C. and Krishnamurthy, N.S., 2006. A generalized 3-D geological and hydrogeological conceptual model of granite aquifers controlled by single or multiphase weathering. Journal of Hydrology, 330(1-2): 260-284.

Haitjema, H.M. and Mitchell-Bruker, S., 2005. Are Water Tables a Subdued Replica of the Topography? Ground Water, 43(6): 781-786.

Healy, R.W. and Cook, P.G., 2002. Using groundwater levels to estimate recharge. Hydrogeology Journal, 10: 91-109.

Ilstedt, U., Malmer, A., Verbeeten, E. and Murdiyarso, D., 2007. The effect of afforestation on water infiltration in the tropics: A systematic review and meta-analysis. Forest Ecology and Management, 251(1-2): 4551.

Jewitt, G., 2005. 186: Water and Forests. In: M. Anderson (Editor), Encyclopedia of Hydrological Sciences. John Wiley Sons, Ltd.

Kresic, N., 1997. Quantitative solutions in hydrogeology and groundwater modeling. Lewis, New York.

Legchenko, A., Descloitres, M., Bost, A., Ruiz, L., Reddy, M., Girard, J.F., Sekhar, M., Mohan Kumar, M.S. and Braun, J.J., 2006. Resolution of MRS Applied to the Characterization of Hard-Rock Aquifers. Ground Water, 44(4): 547-554.

Lerner, D.N., Issar, A.S. and Simmers, I., 1990. Groundwater recharge. A guide to understanding and estimating natural recharge., 8. Heinz Heise, $345 \mathrm{pp}$.

Maréchal, J.C., Dewandel, B., Ahmed, S., Galeazzi, L. and Zaidi, F.K., 2006. Combined estimation of specific yield and natural recharge in a semi-arid groundwater basin with irrigated agriculture. Journal of Hydrology, 329: 281- 293. 
Maréchal, J.C., dewandel, B. and Subrahmanyam, K., 2004. Use of hydraulic tests at different scales to characterize fracture network properties in the weathered-fractured layer of a hard rock aquifer. Water Resources Research, 40.

Möller, D., 1990. Na/Cl ratio in rain water and the sea salt chloride cycle. Tellus, 42: 254-262.

Moyen, J.F., Martin, H. and Jayananda, M., 2001. Multi- element geochemical modeling of crust-mantle interactions during late-Archean crustal growth: the Closepet Granite (South India). Precambrian Research, 112: 87-105.

Nepstad, D.C., de Carvalho, C.R., Davidson, E.A., Jipp, P.H., Lefebvre, P.A., Negreiros, G.H., da Silva, E.D., Stone, T.A., Trumbore, S.E. and Vieira, S., 1994. The role of deep roots in the hydrological and carbon cycles of Amazonian forests and pastures. Nature, 372(6507): 666-669.

Öberg, G. and Sandén, P., 2005. Retention of chloride in soil and cycling of organic matter-bound chlorine. Hydrological Processes, 19(11): 2123-2136.

Peterson, D.M. and Wilson, J.L., 1988. Variably saturated flow between streams and aquifers. Tech Completion Rep 233, New Mexico Water Resources Research Institute, Socorro.

Rangarajan, R. and Athavale, R.N., 2000. Annual replenishable ground water potential of India--an estimate based on injected tritium studies. Journal of Hydrology, 234(1-2): 38-53.

Scanlon, B.R., Keese, K.E., Flint, A.L., Flint, L.E., Gaye, C.B., Edmunds, W.M. and Simmers, I., 2006. Global synthesis of groundwater recharge in semiarid and arid regions. Hydrological Processes, 20(15): 3335 3370 .

Sharda, V.N., Samraj, P., Samra, J.S. and Lakshmanan, V., 1998. Hydrological behaviour of first generation coppiced bluegum plantations in the Nilgiri sub-watersheds. Journal of Hydrology, 211: 50-60.

Sharma, M.L., Barron, R.J.W. and Williamson, D.R., 1987. Soil water dynamics of lateritic catchments as affected by forest clearing for pasture. Journal of Hydrology, 94: 29-46.

Shiva, V. and Bandyopadhyay, J., 1983. Eucalyptus - a disastrous tree for India. The Ecologist, 13: 184-187.

Shivanna, K., Kulkarni, U.P., Joseph, T.B. and Navada, S.V., 2004. Contribution of storms to groundwater recharge in the semi-arid region of Karnataka, India. Hydrological Processes, 18(3): 473-485.

Sorman, A.U., Abdulrazzak, M.J. and Morel-Seytoux, H.J., 1997. Groundwater recharge estimation from ephemeral streams. Case study: Wadi Tabalah, Saudi Arabia. Hydrological Processes, 11: 1607-1619.

Sukhija, B.S., Nagabhushanam, P. and Reddy, D.V., 1996. Groundwater recharge in semi-arid regions of India: an overview of results obtained using tracers. Hydrogeology Journal, 4(3): 50-71.

UNESCO, 1979. Map of the world distribution of arid regions, UNESCO, Paris.

Williamson, D.R., 1990. Salinity - An Old Environmental Problem (abstract), Technical Memorandum No. 90/7 - Division of Water Resources, Inst. of Natural Resources and Environment, CSIRO.

Wood, W.W. and Sanford, W.E., 1995. Chemical and Isotopic Methods for Quantifying Ground-Water Recharge in a Regional, Semiarid Environment. Ground Water, 33(3): 458-468.

Zhang, L., Dawes, W.R. and Walker, G.R., 2001. Response of mean annual evapotranspiration to vegetation changes at catchment scale. Water Resources Research, 37(3): 701-708. 